\title{
Not Just a Bystander: The Emerging Role of Astrocytes and Research Tools in Studying Cognitive Dysfunctions in Schizophrenia
}

\author{
Chia-Yuan Chang ${ }^{1,2,+}$, Da-Zhong Luo ${ }^{1,+}$, Ju-Chun Pei ${ }^{1,+}{ }^{,}$Ming-Che Kuo ${ }^{2,3}$, Yi-Chen Hsieh ${ }^{1}$ \\ and Wen-Sung Lai $1,2,4, *$ (D)
}

1 Department of Psychology, National Taiwan University, Taipei 10617, Taiwan; d03227103@ntu.edu.tw (C.-Y.C.); d06227102@ntu.edu.tw (D.-Z.L.); lagipei@gmail.com (J.-C.P.); r08227134@ntu.edu.tw (Y.-C.H.)

2 Neurobiology and Cognitive Science Center, National Taiwan University, Taipei 10617, Taiwan; kuomingche0402@gmail.com

3 Department of Neurology, National Taiwan University Hospital, Taipei 100225, Taiwan

4 Graduate Institute of Brain and Mind Sciences, National Taiwan University, Taipei 10617, Taiwan

* Correspondence: wslai@ntu.edu.tw; Tel.: +886-2-3366-3112; Fax: +886-2-3362-9909

+ Equal contribution.

check for updates

Citation: Chang, C.-Y.; Luo, D.-Z.; Pei, J.-C.; Kuo, M.-C.; Hsieh, Y.-C.; Lai, W.-S. Not Just a Bystander: The Emerging Role of Astrocytes and Research Tools in Studying Cognitive Dysfunctions in Schizophrenia. Int. J. Mol. Sci. 2021, 22, 5343. https:// doi.org/10.3390/ijms22105343

Academic Editors: Yukihiro Ohno and Schuichi Koizumi

Received: 22 April 2021

Accepted: 14 May 2021

Published: 19 May 2021

Publisher's Note: MDPI stays neutral with regard to jurisdictional claims in published maps and institutional affiliations.

Copyright: (c) 2021 by the authors. Licensee MDPI, Basel, Switzerland. This article is an open access article distributed under the terms and conditions of the Creative Commons Attribution (CC BY) license (https:// creativecommons.org/licenses/by/ $4.0 /)$

\begin{abstract}
Cognitive dysfunction is one of the core symptoms in schizophrenia, and it is predictive of functional outcomes and therefore useful for treatment targets. Rather than improving cognitive deficits, currently available antipsychotics mainly focus on positive symptoms, targeting dopaminergic/serotoninergic neurons and receptors in the brain. Apart from investigating the neural mechanisms underlying schizophrenia, emerging evidence indicates the importance of glial cells in brain structure development and their involvement in cognitive functions. Although the etiopathology of astrocytes in schizophrenia remains unclear, accumulated evidence reveals that alterations in gene expression and astrocyte products have been reported in schizophrenic patients. To further investigate the role of astrocytes in schizophrenia, we highlighted recent progress in the investigation of the effect of astrocytes on abnormalities in glutamate transmission and impairments in the blood-brain barrier. Recent advances in animal models and behavioral methods were introduced to examine schizophrenia-related cognitive deficits and negative symptoms. We also highlighted several experimental tools that further elucidate the role of astrocytes. Instead of focusing on schizophrenia as a neuron-specific disorder, an additional astrocytic perspective provides novel and promising insight into its causal mechanisms and treatment. The involvement of astrocytes in the pathogenesis of schizophrenia and other brain disorders is worth further investigation.
\end{abstract}

Keywords: astrocytes; schizophrenia; cognitive dysfunction; glutamate transmission; glutamate trisynapse; blood-brain barrier; animal models; behavioral tasks

\section{Schizophrenia and Unmet Needs in the Treatment of Schizophrenia}

Schizophrenia is a severe mental disorder that affects approximately $1 \%$ of the world's population and places a great financial burden on our health systems, families, and societies around the world [1]. This debilitating brain disorder typically emerges in late adolescence and early adulthood. Accumulating evidence suggests that genes, environmental insults, and brain changes contribute to the etiopathogenesis of this psychiatric disorder. Major symptoms of schizophrenia include positive symptoms (e.g., hallucinations, delusions, disorganized speech and behaviors), negative symptoms (e.g., blunted affect, alogia, anhedonia, asociality, avolition, poverty of speech), and cognitive deficits (e.g., thought disorders, working memory dysfunction, executive dysfunction, attentional deficits) [2,3]. Schizophrenia is a long-lasting brain disorder that distorts the way a person thinks, behaves, perceives reality, expresses emotions, and relates to others. 
Similar to many other neuropsychiatric disorders, the etiology and pathophysiology of schizophrenia remain unclear. Antipsychotic medications (also known as neuroleptics) are the mainstay of pharmacological treatment for patients with schizophrenia and other psychotic disorders, including schizoaffective disorder, delusional disorder, and bipolar affective disorder, and the major targets of these drugs are positive symptoms of schizophrenia [4]. In contrast, negative symptoms of schizophrenia can often linger or worsen over time, accompanied by impaired cognitive function, such as working memory, executive function, and decision making. Current market antipsychotics have mainly focused on positive and mood-related symptoms, targeting dopaminergic and serotoninergic neurons [5]. In addition, a substantial portion of patients also suffer treatment-resistant positive symptoms, which cannot be improved by even second-generation antipsychotic agents (e.g., clozapine). Cognitive dysfunction is a core feature of schizophrenia that predicts functional outcome and treatment adherence [6]. However, cognitive deficits in schizophrenia have not gained much attention until recently, and available antipsychotic medications are relatively ineffective in improving negative and cognitive deficits. In contrast to the conventional view of dopamine involvement in schizophrenia (i.e., dopamine hypothesis of schizophrenia), other neurotransmitter systems (e.g., glutamatergic and GABAergic neurotransmissions) and glial cells have gradually gained increasing attention in the investigation of the pathophysiology and treatment of schizophrenia in recent decades. The hypothesis that higher cognitive function solely comprises the integrated product of neuronal activity has been challenged by evidence showing the importance of glial cells to both the development and structure of local neural networks.

\section{The Emerging Role of Astrocytes in Schizophrenia}

Traditionally, the importance and significance of glia have long been unappreciated and ignored, even though up to $90 \%$ of the cells in our brain are glial cells, not neurons. Astrocytes, whose name is derived from Greek and means "star-like cells" are a subtype of glial cells that are active dynamic signaling players in the central nervous system (CNS). Astrocytes participate in a variety of essential physiological processes in the brain, such as the formation and maturation of synapses, receptor trafficking, control of the homeostasis of ions and energy metabolites, clearance of neurotransmitters, formation of the bloodbrain barrier (BBB), provision of nutrients to nervous tissue, and regulation of neurogenesis and brain wiring [7]. They also play an important role in the regulation of synaptic activity, plasticity, neural networks, and cognitive functions. The idea that astrocytes play an essential role in higher cognitive functions and contribute to neuropsychiatric disorders has not gained much attention until recent decades.

\subsection{Astrocytic Gene and Astrocyte-Related Gene Expression in Schizophrenia}

Schizophrenia is a highly polygenic brain disorder. Significant progress has been made over the last decades with genetic association studies and genome-wide association studies (GWAS). The glial hypothesis of schizophrenia assumes that initial disturbances in glial cells (especially astrocytes) can lead to abnormalities in neurons and neurotransmitters, which are involved in the pathogenesis of schizophrenia. Genetic studies have revealed a list of astrocyte-related genes associated with schizophrenia, such as $D$-amino acid oxidase (DAO) [8], excitatory amino acid transporter 2 (EAAT2) [9], excitatory amino acid transporter 4 (EAAT4) [10], S100 calcium-binding protein B (S100ß) [11-15], thrombospondin 1 (THBS1) [16], and serine racemase (SR) [17]. These studies indicate that these individual astrocyte-related genes are potentially associated with schizophrenia. However, it remains unclear whether astrocyte pathology that results from astrocyte-specific de novo genetic mutations or neuronal injury triggers astrocyte dysfunction in patients with schizophrenia. Genetic correlations in human studies alone are not enough to establish causation. Complementary to human studies, animal models play an indispensable and important role in advancing the understanding of the etiopathology of schizophrenia and in the development of new treatments. 
In addition, emerging evidence has begun to reveal abnormalities in astrocyte-related gene expression and gene products in patients with schizophrenia. Altered expression of glial fibrillary acidic protein (GFAP) mRNA and hypertrophic astrocyte morphology were found in postmortem tissue of schizophrenic patients [18,19]. Immunohistochemistry data further confirmed a reduction in GFAP protein levels in the white matter of the cingulate cortex in schizophrenic patients [20]. Increased expression of S100B protein, a calcium binding protein and biomarker for astrocytes and oligodendrocytes, has been found in the cortical brain regions (especially dorsolateral prefrontal cortex) of patients with paranoid schizophrenia compared with controls and patients with residual schizophrenia [21]. A meta-regression analysis further indicated that the expression of S100B is negatively correlated with the total score of the Positive and Negative Syndrome Scale in patients [22]. Furthermore, the mRNA level of $Q K I 6 B$, an isoform of quaking (i.e., a gene encoding an RNA-binding protein that is exclusively expressed in glial cells), was upregulated in the prefrontal cortex of patients with schizophrenia [23]. In addition, recent RNA sequencing studies from postmortem brain tissues of schizophrenic patients indicated increased expression of astrocyte-related genes that is independent of medication dosage throughout their lifetime [24]. Thus, findings from these studies support the involvement of astrocytes in the pathogenesis of schizophrenia.

\subsection{The Role of Astrocytes in Cognitive Deficits in Schizophrenia}

In addition to genetic findings of astrocytes in schizophrenia, mounting evidence indicates that astrocytes play a vital role in the maintenance of CNS homeostasis, formation of the BBB, synapse formation, and synaptic glutamate metabolism, which directly or indirectly contribute to the pathogenesis of schizophrenia $[15,25,26]$. Converging lines of evidence also revealed the impact of astrocyte dysfunction on cognitive deficits in schizophrenia. First, human cortical astrocytes are larger and structurally more complex and diverse than infraprimate mammals and rodents $[27,28]$, suggesting that astrocytic complexity supports increased functional competence of the adult human brain and related cognitive capability. Second, a transgenic mouse with specifically inducible tetanus toxin expression in astrocytes demonstrated that astrocytes are necessary for novel object recognition behavior and the maintenance of functional gamma oscillations in vitro and in awake-behaving mice [29]. Findings from this study also revealed an unexpected role for astrocytes as essential contributors to neural information processing and cognitive function in the brain. Third, to assess the cell-autonomous and species-selective properties of human glia, human glial progenitor cells were engrafted into neonatal immunodeficient mice. Human glial chimeric mice displayed enhanced long-term potentiation and learning performance in Barnes maze navigation, object-location memory, and both contextual and tone fear conditioning [30]. Findings from this study indicated that forebrain engraftment of human glial progenitor cells enhances synaptic plasticity and learning in mice, implying that the role of glial cells in neural processing may have expanded with evolution. Fourth, taking advantage of chemogenetic tools, a recent study demonstrated that astrocytes contribute to remote memory formation by modulating hippocampal-cortical communication during learning [31]. Last but importantly, human iPSC glial mouse chimeras were created and revealed a causal role for impaired glial maturation in the development of schizophrenia [32]. In this study, humanized glial chimeric mice were produced from iPSCs derived from patients with childhood-onset schizophrenia to investigate whether intrinsic glial dysfunction contributes to the pathogenesis of schizophrenia. The schizophrenia glial mice showed delayed astrocytic differentiation and abnormal astrocytic morphologies as well as reduced prepulse inhibition and abnormal behaviors. Thus, these studies not only indicate the essential role of astrocytes in neural information processing and cognitive functions but also support the involvement of glial dysfunction in the pathogenesis of schizophrenia. The consequence of astrocyte dysfunction could result in abnormal neurotransmitter release (especially glutamatergic neurotransmission) and cognitive function impairment in schizophrenia. The precise underlying mechanism 
is worth further investigation. Here, we simply highlight two fundamental functions of astrocytes (i.e., BBB formation and modulation of synapse transmission) and their potential roles in the etiopathology of schizophrenia.

\subsection{Astrocytic Modulation of the BBB in Schizophrenia}

As illustrated in Figure 1A, astrocytes play a crucial role in forming the BBB along with pericytes and capillary arterial endothelial cells in the human brain. The BBB separates the human brain from circulating pathogens or metabolized drugs, transports nutrients and secretes growth factors into neuronal cells [33,34], and maintains homeostasis of ions, neurotransmitters, or hormones [35]. The integrity of the BBB relies on tight junctions of endothelial cells and astrocytes connected to neighboring endothelial cells [36]. In particular, astrocytes surrounding the BBB serve as a second barrier to limit the passage into the brain of molecules present in the blood [36]. Accumulated studies have indicated that BBB leakage is detected in patients with mild cognitive impairment or dementia [37,38], suggesting that there is a general link between BBB impairment and the development of cognitive impairment. The increase in BBB permeability has also been considered a biomarker of cognitive dysfunction in Alzheimer's disease [39,40]. Animal studies further showed the strong relationship between BBB impairment and cognitive deficits, including learning [41] and memory [42].

Currently, the gold standard technique for quantifying BBB integrity in humans is measurement of the CSF/serum albumin ratio (QAlb). Albumin is the primary CSF protein, and its concentration is normally 200 times lower than that in blood. An increased QAlb suggests that increased quantities of albumin can pass from blood to CSF because of an impaired barrier. Similar to those findings of cognitive dysfunction in Alzheimer's disease, many studies have shown increased QAlb in patients with schizophrenia [43-48]. In addition to the QAlb measurement, impairment of the BBB was also reported in the blood of patients. In contrast to nearly undetectable $S 100 \beta$ (an astrocytic calcium-binding peptide and an index for BBB dysfunction) in the serum of healthy individuals, increased serum $S 100 \beta$ protein levels were found in medication-free schizophrenic patients [49]. Studies of the postmortem human brain also revealed a reduction in claudin-5, a tight junction-associated protein, in the hippocampus of patients with schizophrenia [26,50]. Thus, the impairment of the BBB caused by the dysfunction of astrocytes would be a possible mechanism underlying the cognitive deficits of schizophrenia, which is worthy of further investigation.

\subsection{Astrocytic Regulation of Glutamate Transmission in Schizophrenia}

In addition to various biological functions, astrocytes also have a fundamental role in glutamate metabolism and neurotransmission. Glutamate is the main excitatory neurotransmitter in the nervous system. Since the discovery of the main glutamate receptor, $\mathrm{N}$-methyl-D-aspartate receptor (NMDAR), in the early 1950s, NMDAR has been implicated in many cognitive functions, including learning and memory [51]. All NMDARs are heteromeric complexes composed of a combination of distinct subunits, including GluN1, CluN2, and GluN3 subunits. As illustrated in Figure 1B, the GluN1 subunit is a strychnineinsensitive site for coagonists D-serine and glycine, and the GluN2 subunit is the agonist binding site for glutamate [52]. NMDARs have a glycine modulatory site (GMS) on GluN1 that must be occupied by glycine/D-serine for glutamate to open the channel. The availability of D-serine depends upon the activities of serine racemase (SR), which converts L-serine to D-serine, and the degrading enzyme D-amino acid oxidase (DAO/DAAO) in astrocytes [53], whereas the availability of glycine in the brain is determined by the activity of the glycine transporter (GlyT1) [54-56]. 


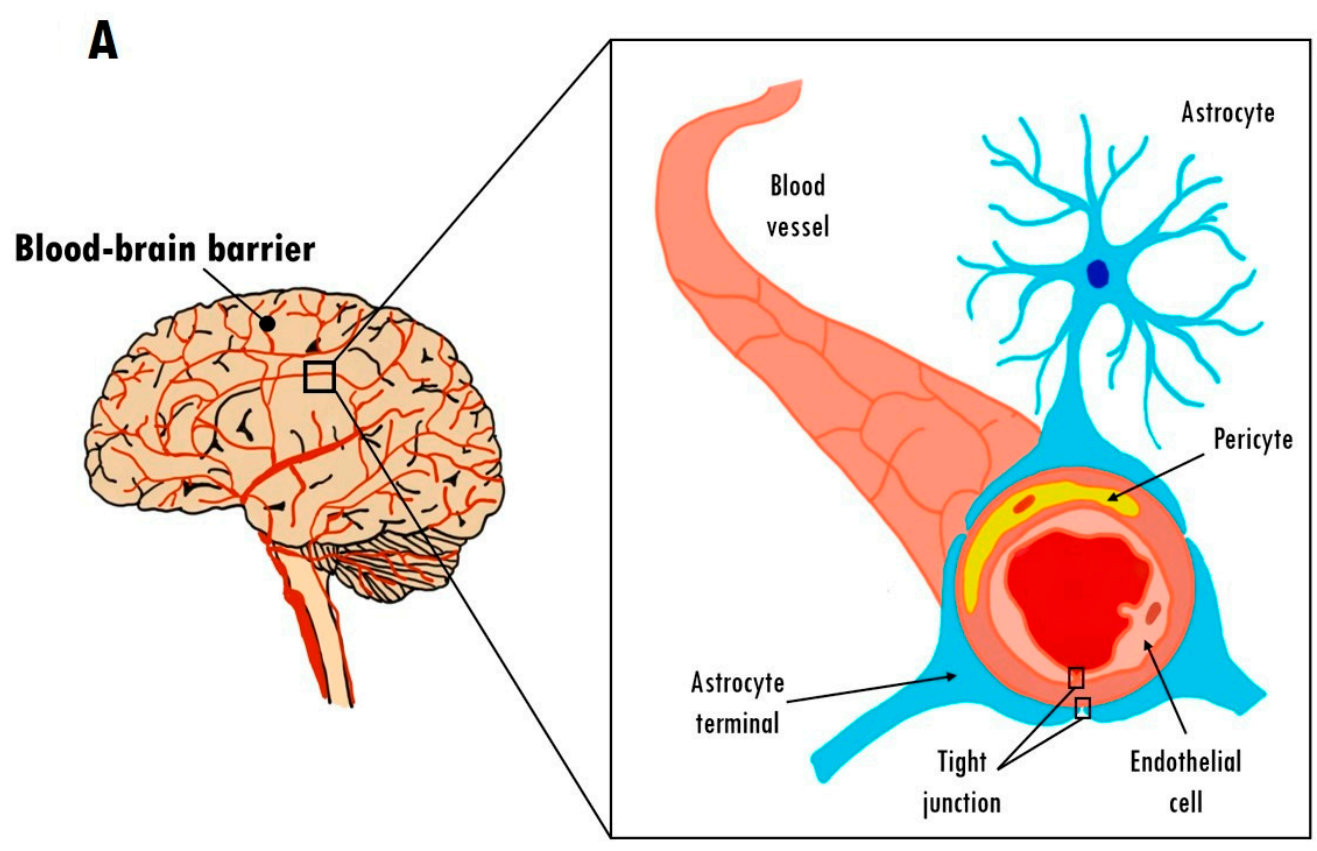

B

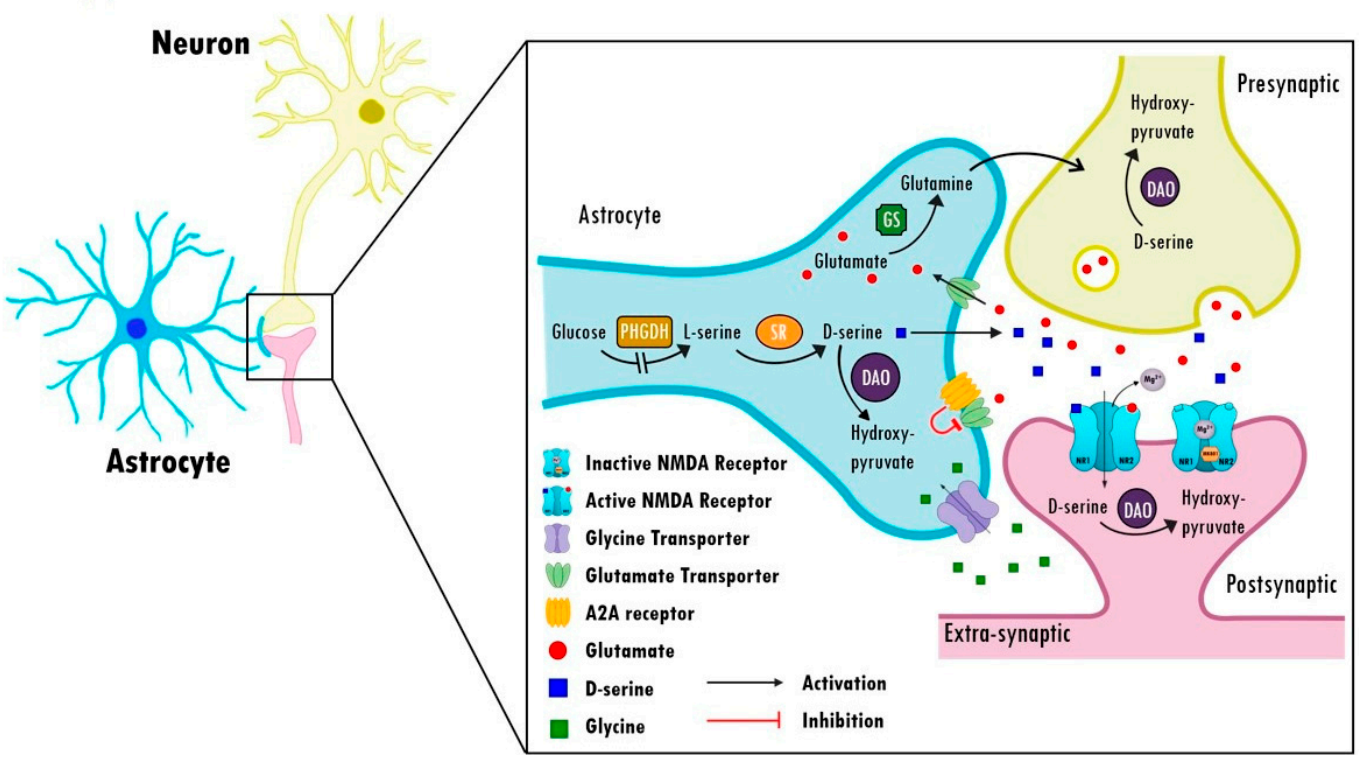

Figure 1. Schematic depiction of the cellular constituents of the blood-brain barrier (BBB) and a model of glutamate trisynapses with presynapses, postsynapses, and astrocytes. (A) The BBB is formed by capillary endothelial cells and pericytes and surrounded by astrocytes. The complex tight junctions of endothelial cells and astrocytes contribute to severely restricted penetration and protect against circulating toxins or pathogens in the brain. (B) In glutamatergic trisynapses, glutamate is released from glutamatergic presynaptic neurons and binds to the GluN2 subunit of NMDARs postsynaptically. Meanwhile, the GluN1 subunit of the NMDARs is occupied by D-serine or glycine, which is released from astrocytes as coagonists to activate NMDARs. The activation of NMDAR removes $\mathrm{Mg}^{2+}$ and opens the ion channel. In astrocytes, glucose is converted to L-serine via the glycolysis pathway with 3-phosphoglycerate dehydrogenase (PHGDH), and then serine racemase (SR) converts L-serine to D-serine, which is released into the synaptic cleft. D-Serine is also metabolized by D-amino acid oxidase (DAO) to hydroxypyruvate in astrocytes. In addition, astrocytes also participate in the glutamateglutamine cycle. Glutamate is taken up by astrocytes and readily converted into glutamine by glutamine synthetase (GS). In return, glutamine is released into the extracellular space and taken into presynaptic terminals. Astrocytic adenosine A2A receptors regulate excitatory amino acid transporter expressions and glutamate uptake. 
Glutamatergic transmission in the vertebrate brain requires the involvement of astrocytes in a continuous molecular dialogue. Astrocytic glutamate receptors and transporters are key molecules that sense synaptic activity and modify their physiology in the short and long terms [57,58]. After glutamate transmission to astrocytes, glutamine synthetase converts glutamate into glutamine. For example, selective removal of oligodendrocyte glutamine synthetase in mice led to a reduction in brain glutamate/glutamine levels and impairment of glutamatergic synaptic transmission [59]. Astrocytes also participate in indirect modulation of NMDARs. Neuronal and glial D-serine production requires astrocytic L-serine generated by a 3-phosphoglycerate dehydrogenase (PHGDH)-dependent pathway $[60,61]$. Astrocyte-derived L-serine shuttles to neurons and fuels the synthesis of D-serine by SR [62]. Dysfunction of PHGDH reduces the synaptic concentration of D-serine [63]. Furthermore, the termination of glycine-mediated synaptic activity through removal of the neurotransmitter from the synaptic cleft also requires specific GlyT1 present in astrocytes [64].

In addition, astrocytic purinergic system also plays an important role in the modulation of glutamatergic signaling. Adenosine acts as a neuromodulator and exerts different functions depending on the type of adenosine receptors and the consequent cellular signaling involved. The increased adenosine concentration has demonstrated its ability to biphasically modulate the evoked release of glutamate from striatal nerve terminals of rats [65]. Adenosine receptors may regulate excitatory amino acid transporter expressions and glutamate uptake in astrocytes. Intriguingly, selective deletion of adenosine A2A receptors from astrocytes in mice disrupts glutamate homeostasis, leading to psychomotor and cognitive impairments, suggesting that adenosine A2A receptors modulate glutamate signaling and thereby influence some psychomotor and cognitive processes associated with schizophrenia [66]. Additionally, adenosine, by acting on adenosine A1 and A2A receptors, has been reported to antagonistically modulate dopaminergic neurotransmission and is therefore involved in psychostimulant-mediated effects, including locomotor activity, discrimination, seeking, reward, and psychostimulant addiction [67]. In contrast, adenosine $\mathrm{A} 2 \mathrm{~B}$ receptors are present in astrocytes, neurons, and microglia, but their role in the CNS is less well characterized. These studies support that the dysfunction of the astrocytic purinergic system may trigger an astrocyte-to-neuron wave of communication resulting in disrupted glutamate homeostasis and dopamine neurotransmission, thought to contribute to some endophenotypes relevant to schizophrenia.

Compared to the long-lasting dopamine hypothesis of schizophrenia, the glutamate hypothesis of schizophrenia has become more promising in recent decades. The glutamate hypothesis of schizophrenia was originally proposed based on the observation that NMDAR antagonists (e.g., phencyclidine and ketamine) induced in healthy individuals positive and negative symptoms that resembled schizophrenia $[68,69]$. Since then, supporting evidence from abnormal expression of NMDAR subunits and NMDAR dysfunction has been implicated in the pathophysiology of schizophrenia [70]. For example, MK-801, a noncompetitive NMDAR antagonist, triggered strong psychomimetic effects with hallucinations and other psychomotor signs that resemble schizophrenia [71]. Given that released glutamate is taken up by surrounding astrocytes, impaired astrocytes can lead to dysfunction of the glutamatergic transmission system and hypofunction of NMDARs in schizophrenia. Postmortem examinations revealed that the cortical expression of astrocytes, glutamate type II, aquaporin-4, S100B, glutaminase, GLT-1, thrombospondin, GFAP, and glutamine synthetase was significantly reduced in the brains of patients with schizophrenia [72,73], supporting the possibility of astrocyte-involved glutamatergic dyshomeostasis in these patients. In addition, evidence suggests that abnormalities in the localization and function of astrocytic glutamate transporters may underlie a disease mechanism with pathological glutamate spillover as well as alterations in the kinetics of perisynaptic glutamate buffering and uptake, which might contribute to the pathophysiology of schizophrenia. An increase in transporter expression in neurons reportedly compensates for the loss of transporter expression in astrocytes [74], which further suggests a profound abnormal- 
ity in astrocyte functions and their interactions with neurons in the pathophysiology of schizophrenia. Accordingly, the abovementioned studies highlighted two fundamental roles of astrocytes and their involvement in cognitive dysfunctions and schizophrenia. However, the precise underlying mechanism and causal relationship between astrocytes and cognitive dysfunction in schizophrenia still need further elucidation.

\section{Taking Advantage of Mouse Models and Experimental Tools to Study Astrocytes and Cognitive Deficits in Schizophrenia}

Complementary to human studies, applying genetic mutations or pharmacological treatments in animal models provides an efficient opportunity to understand the underlying mechanisms and causal relationship of the pathophysiology of schizophrenia $[75,76]$. Appropriate animal models with suitable experimental tools provide opportunities to investigate behavioral, functional, structural, and molecular abnormalities at different stages of diseases [75,77]. Currently, along with drug-induced models of schizophrenia, the construction of mice with targeted mutations via gene knockout or transgenic techniques has demonstrated the ability to uniquely identify the functional significance of the targeted gene and its encoded protein with etiological validity $[78,79]$. As illustrated in Figure 2, a selection of animal models for schizophrenia and experimental techniques was highlighted and introduced to investigate the involvement and roles of astrocytes in the cognitive deficits of schizophrenia.

\subsection{Using Animal Models to Investigate Astrocytic Regulation of Glutamate Transmission in Schizophrenia}

Astrocytes regulate multiple processes in the brain and serve as an integration hub for homeostasis to maintain neuronal functions and modulate metabolic exchange through the BBB [80]. It is therefore not surprising that astrocyte dysfunctions are involved in behavioral abnormalities resembling schizophrenia and in the pathogenesis of some clinical symptoms of schizophrenia. Converging evidence indicates that astrocytes are essential and dynamic partners in both glutamatergic and GABAergic neurotransmissions in the brain [81]. The maintenance of these neurotransmitter pools is strictly dependent on the de novo synthesis of glutamine in astrocytes. As illustrated in the upper panels of Figure 2, the drug-induced and genetically engineered mouse models of astrocyte dysfunction provide a straightforward approach for advancing our understanding of the roles of astrocytes in schizophrenia, and they allow us to directly alter glutamate signaling through manipulation of glutamate, D-serine, and glycine [80]. Indeed, one of the major functions of astrocytes is glutamate uptake, which plays a vital role in the synaptic transmission of glutamate. Glutamate is taken up via glutamate transporter-1 (GLT-1) and converted to glutamine by glutamine synthetase (GS) in astrocytes. Abnormalities of GLT-1 and GS were found in the prefrontal cortex of schizophrenic patients [82-84]. Rats treated with ceftriaxone, a GLT-1 activator, displayed increased expression and activity of GLT- 1 in astrocytes and impaired sensorimotor gating function, learning, and memory $[85,86]$. Mice treated with methionine sulfoximine injection (an inhibitor of GS) displayed hypoactive GS activity, resulting in low active glutamatergic signaling in the CA3 region of the hippocampus and impaired spatial memory function [87]. Moreover, astrocytic adenosine receptors A2A play an important role in regulating glutamate uptake and preventing glutamate accumulation $[66,88]$. A selective deletion of A2A receptors in astrocytes in mice (i.e., Gfa2-A2AR knockout mice) resulted in disrupted glutamate homeostasis, which underlies several endophenotypes relevant to schizophrenia [66]. These Gfa2-A2AR knockout mice exhibited aberrant GLT-1 activity, increased presynaptic glutamate release, GluN2B upregulation, increased internalization of AMPA receptors, as well as enhanced MK-801 psychomotor responses and decreased working memory. These studies highlight the importance of glutamate and support the involvement of astrocytes in the pathogenesis of schizophrenia. The precise role of glutamate transmission in astrocytes and its involvement in cognitive deficits in schizophrenia are worth further investigation. 


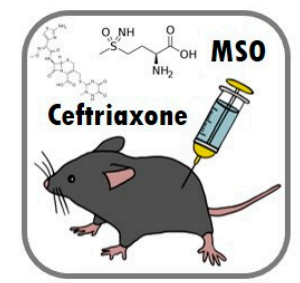

Pharmaceutical injection

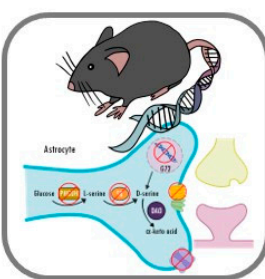

Genetic mutation

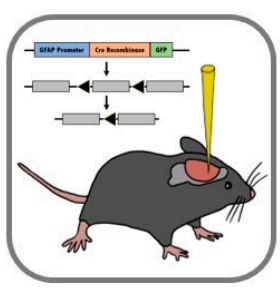

GFAP-cre

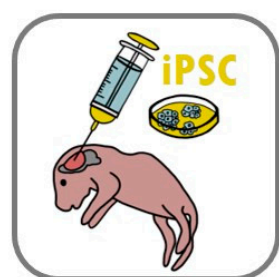

iPSC transplantation

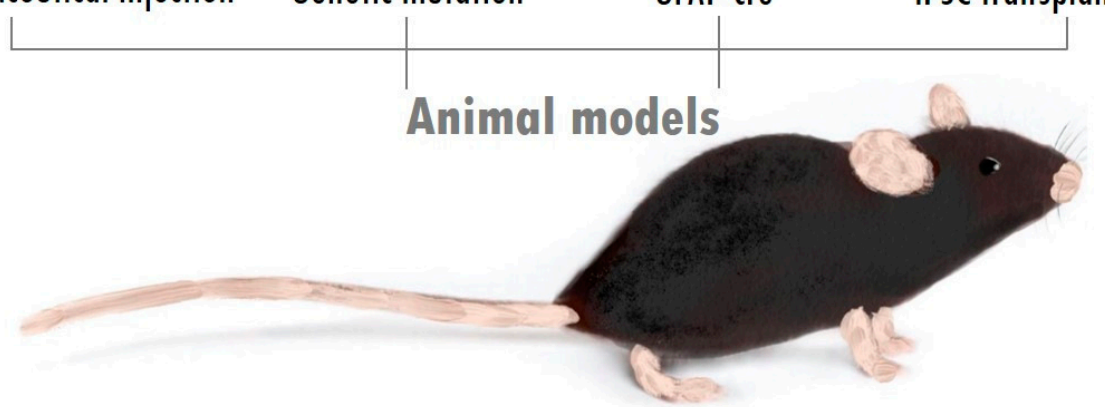

Behavioral tasks

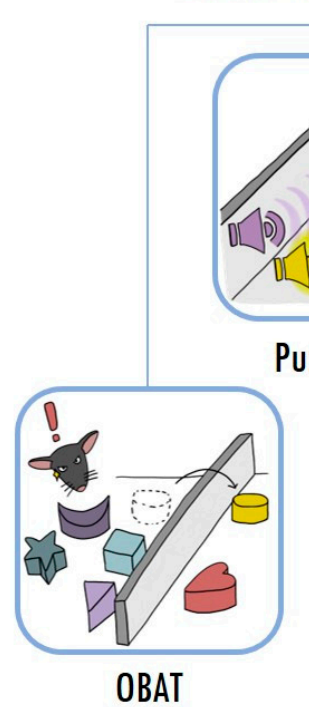

Puzzle box
Experimental techniques

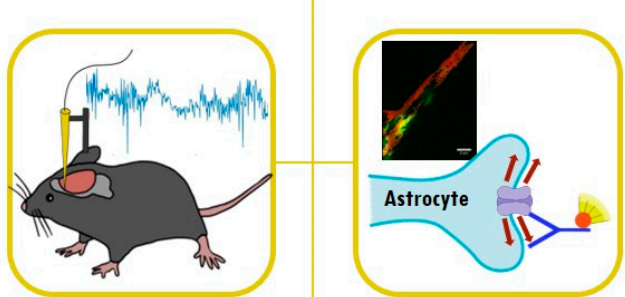

Electrophysiology Single particle tracking

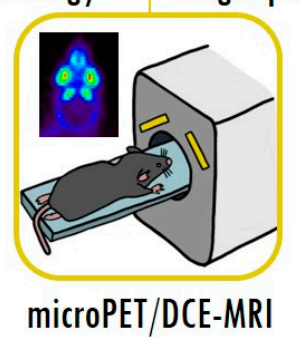

Figure 2. A selection of experimental tools for investigating the role of astrocytes in cognitive deficits in schizophrenia. (The upper panels) Astrocyte-related animal models of schizophrenia, including (from left to right) drug-induced models (such as methionine sulfoximine (MSO) and ceftriaxone injections), genetic mutant mouse models (such as G72, SR, PHGDH, GlyT1 mutant mice, and Gfa2-A2AR knockout mice), GFAP-cre mice, and human iPSC transplantation mice. (The lower left panels) A selection of three behavioral tasks for assessing schizophrenia-like cognitive deficits and negative symptoms in animal models. The puzzle box and object-based attention test (OBAT) can be used to assess cognitive function. Effort-based tasks can be used to measure negative symptoms. (The lower right panels) A selection of four experimental techniques to examine the function of astrocytes. Electrophysiological recording is useful for understanding astrocyte-mediated neuronal transmission and oscillation. Single particle tracking can be used to record the trajectory of receptors or proteins on astrocytic membranes. The specific PET radiotracers ${ }^{18}$ F-FDG and ${ }^{11} \mathrm{C}$-DED quantify astrocyte-related physiological, biochemical, and functional processes. Dynamic contrast-enhanced MRI (DCE-MRI) can be used to assess BBB integrity.

In addition to glutamate, D-serine and glycine act as coagonists of the NMDAR glycine modulatory site and contribute to the pathophysiology of schizophrenia [89]. GlyT1 is the major glycine transporter subunit at glutamatergic synapses and is expressed in presynaptic and postsynaptic terminals and astrocytes, contributing to decreased extracellular glycine concentrations at the synaptic cleft $[90,91]$. GlyT1-deficient mouse models have been used to evaluate the preclinical in vivo efficacy of drug candidates for enhancing NMDAR function in the treatment of schizophrenia-like symptoms, especially cognitive- 
related deficits [90,92-94]. In addition, as mentioned previously, glucose is converted to L-serine via the glycolysis pathway with PHGDH [60,95], and then SR converts L-serine to D-serine [96]; meanwhile, D-serine is metabolized by D-amino acid oxidase (DAO) [97] in astrocytes. A previous study indicated that a PHGDH antagonist inhibits NMDAR synaptic activation in the hippocampal CA1 region of the mouse brain [62], and PHGDH knockout in mice leads to serine and glycine deficiency and embryonic lethality [98]. Moreover, PHGDH conditional knockout mice were not embryonic lethal; however, microcephaly, decreased L-serine, D-serine and glycine in astrocytes, and impaired LTP and spatial memory were observed $[63,99]$. Alternatively, although recent studies report that SR and DAO are not solely expressed in astrocytes [100-102], astrocytes play a vital role in the secretion of D-serine and the regulation of NMDAR function $[96,103]$. Several animal studies with constitutive deletion of $S R$ in $S R^{-/}$mutant mice indicated that these mice had long-term D-serine deficiency, neurobiological abnormalities, spatial and fear memory deficits, sociality problems, and hyperlocomotion activity [104-108]. Intriguingly, a recent study further indicated that $S R^{-/-}$mutant mice exhibited a reduction in the freezing response in the trace fear conditioning task and hyperlocomotion in the open-field task, which were normalized by a single administration of sarcosine (an astrocytic glycine transporter-1 inhibitor) [108]. However, little is known about NMDAR hypofunction induced by DAO overexpression in animal models.

In contrast, the G72 protein, also known as a DAO activator, has been detected in astrocytes and regulates DAO activity and D-serine levels [109,110]. Specifically, G72 transgenic mice exhibited deficits in motor coordination, social ability, prepulse inhibition (PPI), learning and memory, and synaptic transmission in the hippocampus, all of which reflect the symptoms of schizophrenia [111-113]. Furthermore, GFAP-cre mice and human iPSC transplantation mice represent advanced models that focus on the causal relationship between astrocytes and schizophrenia. For example, taking advantage of GFAP-cre mice, mice with deletion of both interleukin- 6 and interleukin- 6 receptors in astrocytes displayed alterations in locomotor activity, anxiety, and exploratory behaviors [114]. Mice transplanted with schizophrenia iPSCs show delayed astrocytic differentiation, abnormal astrocytic morphologies, and reduced PPI as well as schizophrenia-related behavior [32]. Collectively, apart from the neuronal aspect of schizophrenia, these astrocyte-related animal models provide a better understanding of the pathogenesis of schizophrenia from the aspect of astrocytes and provide additional therapeutic targets for the treatment of schizophrenia.

\subsection{A Selection of Behavioral Tasks for Assessing Cognitive Deficits and Negative Symptoms of Schizophrenia in Animal Models}

Schizophrenia is a psychiatric disorder in humans. Generating "ideal" animal models that recapitulate the full phenotypic spectrum of schizophrenia is nearly impossible. Although we are still far from understanding the precise etiologies and pathogenesis of schizophrenia, many appropriate experimental designs and behavioral tasks in animal models can help clarify and answer these questions. Conventional behavioral tasks have been developed or adopted to evaluate schizophrenia-relevant behavioral phenotypes in mouse models [75-77,115]. For example, animals administered psychostimulants in the open field test can be tested using psychomotor agitation for positive symptom-related behavior; social preference tasks and sucrose preference tasks are relevant to sociality and anhedonia, respectively, which have been used to investigate negative symptomrelated behaviors; and cognitive dysfunction in schizophrenia, such as sensorimotor gating deficits or learning and memory problems, can be examined in the PPI and Morris water maze, respectively. To date, pharmacological treatments for negative and cognitive symptoms of schizophrenia are still unmet medical needs. Consequently, here, we focus on the negative and cognitive symptoms and highlight three specific behavioral tasks for measuring schizophrenia-related cognitive deficits in mice, including problem solving, attention, and motivation, as illustrated in the lower left panels of Figure 2. These specific cognitive functions were identified by the Measurement and Treatment Research to Improve Cognition in Schizophrenia (MATRICS) [116] and Cognitive Neuroscience Treatment 
Research to Improve Cognition in Schizophrenia (CNTRICS) criteria [117]. They are of particular interest for the measurement of specific core features of schizophrenia. Moreover, deficits in these cognitive functions have also prompted researchers to develop cognitive remediation therapy for the treatment of patients with schizophrenia [118]. Indeed, in a recent systematic review and meta-analysis, cognitive remediation was confirmed as effective on both cognitive and functional outcomes and potentially useful for all patients with schizophrenia, even those most severely affected [119]. Thus, in complementary to human studies, it is worth investigating and developing animal models representing and mimicking cognitive processes in humans.

Cognitive impairments are considered a core feature of schizophrenia [120]. Problemsolving ability (or executive function) is an important cognitive ability, but it is challenging to measure in animals. Inspired by mental rotation and perseverance tasks in humans, a puzzle box originally designed for rats in 1995 [121] and later modified for mice [122,123] is a simple and efficient behavioral task for evaluating general cognition and executive functions in mouse models of schizophrenia [124,125]. Briefly, each experimental mouse was placed in an apparatus divided into two compartments: a brightly-lit, spacious start zone with loud noises and a smaller covered goal zone without a noise. In each trial, each mouse started from the start zone and then went into the goal zone through a narrow underpass blocked by different obstructions in order to escape from the bright lights and loud noises. Following nine trials over three consecutive days with increased difficulties, it was possible to measure problem-solving ability and short-term and long-term memory in mice [124]. Previous studies demonstrated that both MK-801-treated mice and GluN1 subunit knockdown mice exhibited deficits in the puzzle box task, indicating that the puzzle box is an effective screening tool for investigating executive functions in NMDAR hypofunction mouse models of schizophrenia [124,125].

In addition, attention impairment is also commonly observed among schizophrenic patients and individuals with genetic risks for schizophrenia [2,126]. The 5-choice serial reaction time task (5-CSRTT) is widely used to measure attentional functions in rodents, and it has been applied to model attentional dysfunction in schizophrenia [115,127]. However, there are some drawbacks of 5-CSRTT, including long training sessions, vast experimenter effort, chronic stress in experimental animals, etc. [128]. Many researchers need an efficient behavioral task that assesses attentional functions to be developed. Taking advantage of the natural tendency in mice to explore novelty, an object-based attention (OBA) task was established as a simple and practical behavioral task for evaluating attentional function in mice $[129,130]$. In this task, mice were first allowed to explore five different but similar objects in the exploratory chamber for a 3 min training phase, and then they were immediately transferred to the test chamber where they explored one familiar object and one novel object during a $3 \mathrm{~min}$ testing phase. The time spent exploring each object was recorded in each chamber, and a recognition (i.e., novel vs. familiar objects) index was calculated to indicate attentional function. For verification, the OBA task was confirmed in an attention deficit model induced by acute phencyclidine $(1 \mathrm{mg} / \mathrm{kg}$, i.p.) treatment in mice [129]. It is implied that not only can the OBA task assist the behavioral screening process of pharmacological studies on attention-improving drugs but also can evaluate attentional functions in mouse models of schizophrenia. Moreover, unlike the currently available tasks for assessing attention with food/liquid reinforcers, the response bias and uncertainty in the result can be reduced in the OBA task.

Additionally, motivation is a complex and multifaceted process that induces behavioral activation to exert the effort necessary for survival [131]. Previous studies have revealed that motivation-induced behavioral activation is relevant for investigating psychopathology [131]. Indeed, avolition, lack of motivation, is characterized as a negative symptom of schizophrenia [132]. Thus, the behavioral tasks of motivational dysfunctions could foster pathologies and lead to drug treatment for negative symptoms of schizophrenia. Over the past few decades, an emerging area of research has focused on effort-based decision making. Currently, two effort-based decision-making tasks are available, in- 
cluding the concurrent lever-pressing/chow-feeding choice task $[133,134]$ and the T-maze barrier choice task $[135,136]$. In the concurrent lever-pressing/chow-feeding choice task, each animal was allowed to choose either a lever with a progressive ratio for high rewards or another lever for free approach to low rewards. Similarly, in the T-maze barrier choice task, each animal was allowed to choose either a runway with a vertical barrier for a large amount of reinforcement or another runway with no barrier for a lower amount of reinforcement. As the task difficulty increased, the motivation to choose the high effort option declined in these mice/rats. Both the mesostriatal DA pathway and the glutamate and GABA systems are involved in the process of motivation $[131,137,138]$. Thus, effort-based decision-making tasks provide a suitable behavioral measurement for investigating the neural mechanisms underlying motivation and the involvement of astrocyte dysfunction in cognitive deficits.

\subsection{Experimental Tools to Evaluate the Function of Astrocytes}

In addition to the abovementioned specific behavioral tasks, multiple analytical tools and neurobiological techniques provide further insight into astrocyte dysfunction and its involvement in the pathophysiology of schizophrenia. As illustrated in the lower right panels of Figure 2, four powerful techniques for investigating biomolecular functions and structures are highlighted here as examples. First, analysis of electrophysiological endophenotypes of NMDAR-mediated transmission is a widely used method for understanding pathological neuronal networks and tripartite synaptic signal integrations $[139,140]$. For example, sarcosine, an astrocytic glycine transporter-1 inhibitor, enhanced NMDARmediated field excitatory postsynaptic potentials and bound to the GMS of NMDARs in the CA1 region of mouse hippocampal slices [108]. Both in vitro electrophysiological studies $[29,141,142]$ and in vivo experiments $[29,143,144]$ with cell type-specific recordings were proven to be useful in revealing that astrocytes mediate neuronal transmission and oscillation. Second, molecular imaging with positron emission tomography (PET) provides the quantification of diverse physiological, biochemical, and functional processes in schizophrenic patients and animal models [108,145-148]. Intriguingly, the most commonly used PET radiotracer, ${ }^{18}$ F-FDG, is driven by astrocytic glutamate transport [149]. For example, ${ }^{18}$ F-FDG PET/CT brain images revealed that the injection of MK-801 increased overall brain activity, and treatment with sarcosine significantly normalized MK-801-induced abnormalities in the mouse brain [108]. In addition, the best-known PET radiotracer for astrocytes is ${ }^{11} \mathrm{C}$-deuterium-L-deprenyl $\left({ }^{11} \mathrm{C}\right.$-DED), and it has been employed as a biomarker of astrocytosis in pathologies such as Alzheimer's disease [150,151]. ${ }^{11} \mathrm{C}-\mathrm{DED}$ is an irreversible monoamine oxidase $\mathrm{B}$ (MAO-B) inhibitor, and the potential application of ${ }^{11} \mathrm{C}$-DED MRI has been demonstrated in detecting astrocyte function in patients with schizophrenia [152,153]. Third, to noninvasively assess the integrity of the BBB, an innovative neuroimaging technique called dynamic contrast-enhanced MRI (DCE-MRI) has also been developed. BBB breakdown could be seen on DCE-MRI by the extravasation of contrast medium into the brain parenchyma. Moreover, DCE-MRI can also be used to detect BBB integrity in animal disease models, such as stroke [154], traumatic brain injury [155], and Alzheimer's disease [156]. The considerable technical progress of DCE-MRI in combination with PET scans provides not only BBB permeability measurements but also information on CNS transport and lymphatic drainage in the CNS [157]. This system demonstrated an alternative method for exploring the pharmacokinetic aspects of chemical entities with CSF transport through the BBB. However, DCE-MRI has not been applied to schizophrenia in either humans or animals. While techniques for visualizing the $\mathrm{BBB}$ are emerging, there is a great chance to deduce the specific role of astrocytes and BBB integrity in various neuropsychiatric disorders. Last, single particle tracking is a revolutionized tool for interrogating dynamics in live cells because of its ability to reveal dynamics in the structure-function relationships underlying the heterogeneous nature of such systems $[158,159]$. For example, taking advantage of single particle tracking on the GluN1 subunit of NMDARs, a recent study indicated the surface dynamics and movement 
of NMDARs before and after sarcosine treatment in cultured hippocampal neurons from 18-day-old rat embryos [108]. Single particle tracking techniques with specific quantum dots can be used to record the trajectory from the motion of receptors or proteins on astrocyte membranes [160-162] and the behaviors of membrane molecules, which reflect the condition of astrocytes in pathological disease states [163]. Collectively, the abovementioned techniques are worth applying to explore the pathogenesis of astrocyte dysfunction in animal models of schizophrenia and to further develop effective therapeutics for the treatment of schizophrenia.

\section{Summary and Conclusions}

Unfortunately, the etiology and pathophysiology of schizophrenia remain unclear. Pharmacological treatment for negative symptoms and cognitive deficits of schizophrenia has become an unmet medical need. Apart from investigating the neural mechanisms underlying schizophrenia, emerging evidence has begun to reveal the importance and involvement of astrocytes in schizophrenia, especially with regard to cognitive functions. A selection of animal models and experimental tools have been introduced and highlighted for investigating the role of astrocytes in the pathogenesis of schizophrenia and cognitive dysfunctions. A selection of three behavioral tasks is recommended for investigating schizophrenia-related cognitive deficits (i.e., puzzle box for problem solving and OBA test for attentional function) and negative symptoms (i.e., effort-based decision-making tasks for motivation) in animal models. Here, we described the current knowledge pertaining to astrocytes' role in the pathogenesis of schizophrenia and introduced useful experimental models and tools to further elucidate the role of astrocytes in the cognitive deficits of schizophrenia. Collectively, emerging evidence suggests that astrocytes are not just bystanders but are involved in the pathophysiology of schizophrenia. Given that astrocytes participate in a variety of essential physiological processes in the CNS, it would also be beneficial to use these astrocyte-related animal models and experimental tools to investigate their involvement in other neuropsychiatric disorders, as reported previously for Rett syndrome [164], Fragile X syndrome [165], major depressive disorder [166], bipolar disorder [167], Alzheimer's disease [168], Prader-Willi syndrome [169], Parkinson's disease [170], etc. The precise role and underlying mechanism of astrocytes are worth further investigation.

Funding: This research was supported by grant numbers 108-2410-H-002-104, 109-2918-I-002-008, 109-2926-I-002-509, and 109-2410-H-002-087-MY3 from the Ministry of Science and Technology in Taiwan to WS Lai and by grant support from National Taiwan University and National Taiwan University Hospital.

Institutional Review Board Statement: Not applicable.

Informed Consent Statement: Not applicable.

Data Availability Statement: Not applicable.

Acknowledgments: We thank all members of the Laboratory of Integrated Neuroscience and Ethology (LINE) in the Department of Psychology, National Taiwan University, for their assistance and comments.

Conflicts of Interest: The author(s) declare no potential conflict of interest with respect to the research, authorship, and/or publication of this article.

\section{References}

1. Abbott, A. Schizophrenia: The drug deadlock. Nature 2010, 468, 158-159. [CrossRef]

2. Green, M.F.; Kern, R.S.; Heaton, R.K. Longitudinal studies of cognition and functional outcome in schizophrenia: Implications for MATRICS. Schizophr. Res. 2004, 72, 41-51. [CrossRef] [PubMed]

3. Lien, Y.J.; Tsuang, H.C.; Chiang, A.; Liu, C.M.; Hsieh, M.H.; Hwang, T.J.; Liu, S.K.; Hsiao, P.C.; Faraone, S.V.; Tsuang, M.T.; et al. The multidimensionality of schizotypy in nonpsychotic relatives of patients with schizophrenia and its applications in ordered subsets linkage analysis of schizophrenia. Am. J. Med. Genet. B Neuropsychiatr. Genet. 2010, 153B, 1-9. [CrossRef] [PubMed] 
4. Elert, E. Aetiology: Searching for schizophrenia's roots. Nature 2014, 508, S2-S3. [CrossRef] [PubMed]

5. Citrome, L.; Stensbol, T.B.; Maeda, K. The preclinical profile of brexpiprazole: What is its clinical relevance for the treatment of psychiatric disorders? Expert Rev. Neurother. 2015, 15, 1219-1229. [CrossRef]

6. Koychev, I.; Joyce, D.; Barkus, E.; Ettinger, U.; Schmechtig, A.; Dourish, C.T.; Dawson, G.R.; Craig, K.J.; Deakin, J.F. Cognitive and oculomotor performance in subjects with low and high schizotypy: Implications for translational drug development studies. Transl. Psychiatry 2016, 6, C. [CrossRef] [PubMed]

7. Gentile, M.T.; D'Amato, L.C. Astrocyte-Physiology and Pathology. 2018. Available online: https://www.intechopen.com/books/ astrocyte-physiology-and-pathology (accessed on 18 May 2021).

8. Roussos, P.; Giakoumaki, S.G.; Adamaki, E.; Georgakopoulos, A.; Robakis, N.K.; Bitsios, P. The association of schizophrenia risk D-amino acid oxidase polymorphisms with sensorimotor gating, working memory and personality in healthy males. Neuropsychopharmacology 2011, 36, 1677-1688. [CrossRef] [PubMed]

9. Spangaro, M.; Bosia, M.; Zanoletti, A.; Bechi, M.; Cocchi, F.; Pirovano, A.; Lorenzi, C.; Bramanti, P.; Benedetti, F.; Smeraldi, E.; et al. Cognitive dysfunction and glutamate reuptake: Effect of EAAT2 polymorphism in schizophrenia. Neurosci. Lett. 2012, 522, 151-155. [CrossRef] [PubMed]

10. Deng, X.; Shibata, H.; Takeuchi, N.; Rachi, S.; Sakai, M.; Ninomiya, H.; Iwata, N.; Ozaki, N.; Fukumaki, Y. Association study of polymorphisms in the glutamate transporter genes SLC1A1, SLC1A3, and SLC1A6 with schizophrenia. Am. J. Med. Genet. B Neuropsychiatr. Genet. 2007, 144B, 271-278. [CrossRef]

11. Bernstein, H.G.; Steiner, J.; Bogerts, B. Glial cells in schizophrenia: Pathophysiological significance and possible consequences for therapy. Expert Rev. Neurother. 2009, 9, 1059-1071. [CrossRef] [PubMed]

12. Liu, J.; Shi, Y.; Tang, J.; Guo, T.; Li, X.; Yang, Y.; Chen, Q.; Zhao, X.; He, G.; Feng, G.; et al. SNPs and haplotypes in the S100B gene reveal association with schizophrenia. Biochem. Biophys Res. Commun. 2005, 328, 335-341. [CrossRef] [PubMed]

13. Hohoff, C.; Ponath, G.; Freitag, C.M.; Kastner, F.; Krakowitzky, P.; Domschke, K.; Koelkebeck, K.; Kipp, F.; von Eiff, C.; Deckert, J.; et al. Risk variants in the S100B gene predict elevated S100B serum concentrations in healthy individuals. Am. J. Med. Genet. B Neuropsychiatr. Genet. 2010, 153B, 291-297. [CrossRef] [PubMed]

14. Zhai, J.; Zhang, Q.; Cheng, L.; Chen, M.; Wang, K.; Liu, Y.; Deng, X.; Chen, X.; Shen, Q.; Xu, Z.; et al. Risk variants in the S100B gene, associated with elevated S100B levels, are also associated with visuospatial disability of schizophrenia. Behav. Brain Res. 2011, 217, 363-368. [CrossRef]

15. Bernstein, H.G.; Steiner, J.; Guest, P.C.; Dobrowolny, H.; Bogerts, B. Glial cells as key players in schizophrenia pathology: Recent insights and concepts of therapy. Schizophr. Res. 2015, 161, 4-18. [CrossRef]

16. Park, H.J.; Kim, S.K.; Kim, J.W.; Kang, W.S.; Chung, J.H. Association of thrombospondin 1 gene with schizophrenia in Korean population. Mol. Biol. Rep. 2012, 39, 6875-6880. [CrossRef]

17. Morita, Y.; Ujike, H.; Tanaka, Y.; Otani, K.; Kishimoto, M.; Morio, A.; Kotaka, T.; Okahisa, Y.; Matsushita, M.; Morikawa, A.; et al. A genetic variant of the serine racemase gene is associated with schizophrenia. Biol. Psychiatry 2007, 61, 1200-1203. [CrossRef]

18. Catts, V.S.; Wong, J.; Fillman, S.G.; Fung, S.J.; Shannon Weickert, C. Increased expression of astrocyte markers in schizophrenia: Association with neuroinflammation. Aust. N Z J. Psychiatry 2014, 48, 722-734. [CrossRef] [PubMed]

19. Webster, M.J.; O'Grady, J.; Kleinman, J.E.; Weickert, C.S. Glial fibrillary acidic protein mRNA levels in the cingulate cortex of individuals with depression, bipolar disorder and schizophrenia. Neuroscience 2005, 133, 453-461. [CrossRef] [PubMed]

20. Williams, M.; Pearce, R.K.; Hirsch, S.R.; Ansorge, O.; Thom, M.; Maier, M. Fibrillary astrocytes are decreased in the subgenual cingulate in schizophrenia. Eur. Arch. Psychiatry Clin. Neurosci. 2014, 264, 357-362. [CrossRef]

21. Steiner, J.; Bernstein, H.G.; Bielau, H.; Farkas, N.; Winter, J.; Dobrowolny, H.; Brisch, R.; Gos, T.; Mawrin, C.; Myint, A.M.; et al. S100B-immunopositive glia is elevated in paranoid as compared to residual schizophrenia: A morphometric study. J. Psychiatr. Res. 2008, 42, 868-876. [CrossRef]

22. Schumberg, K.; Polyakova, M.; Steiner, J.; Schroeter, M.L. Serum S100B Is Related to Illness Duration and Clinical Symptoms in Schizophrenia-A Meta-Regression Analysis. Front. Cell Neurosci. 2016, 10, 46. [CrossRef]

23. Farnsworth, B.; Radomska, K.J.; Zimmermann, B.; Kettunen, P.; Jazin, E.; Emilsson, L.S. QKI6B mRNA levels are upregulated in schizophrenia and predict GFAP expression. Brain Res. 2017, 1669, 63-68. [CrossRef]

24. Gonzalez-Penas, J.; Costas, J.; Villamayor, M.J.G.; Xu, B. Enrichment of rare genetic variants in astrocyte gene enriched co-expression modules altered in postmortem brain samples of schizophrenia. Neurobiol. Dis. 2019, 121, 305-314. [CrossRef] [PubMed]

25. Dietz, A.G.; Goldman, S.A.; Nedergaard, M. Glial cells in schizophrenia: A unified hypothesis. Lancet Psychiatry 2020, 7, 272-281. [CrossRef]

26. Greene, C.; Hanley, N.; Campbell, M. Blood-brain barrier associated tight junction disruption is a hallmark feature of major psychiatric disorders. Transl. Psychiatry 2020, 10, 373. [CrossRef] [PubMed]

27. Oberheim, N.A.; Takano, T.; Han, X.; He, W.; Lin, J.H.; Wang, F.; Xu, Q.; Wyatt, J.D.; Pilcher, W.; Ojemann, J.G.; et al. Uniquely hominid features of adult human astrocytes. J. Neurosci. 2009, 29, 3276-3287. [CrossRef] [PubMed]

28. Oberheim, N.A.; Wang, X.; Goldman, S.; Nedergaard, M. Astrocytic complexity distinguishes the human brain. Trends Neurosci. 2006, 29, 547-553. [CrossRef] [PubMed]

29. Lee, H.S.; Ghetti, A.; Pinto-Duarte, A.; Wang, X.; Dziewczapolski, G.; Galimi, F.; Huitron-Resendiz, S.; Pina-Crespo, J.C.; Roberts, A.J.; Verma, I.M.; et al. Astrocytes contribute to gamma oscillations and recognition memory. Proc. Natl. Acad. Sci. USA 2014, 111, E3343-E3352. [CrossRef] 
30. Han, X.; Chen, M.; Wang, F.; Windrem, M.; Wang, S.; Shanz, S.; Xu, Q.; Oberheim, N.A.; Bekar, L.; Betstadt, S.; et al. Forebrain engraftment by human glial progenitor cells enhances synaptic plasticity and learning in adult mice. Cell Stem Cell 2013, 12, 342-353. [CrossRef]

31. Kol, A.; Adamsky, A.; Groysman, M.; Kreisel, T.; London, M.; Goshen, I. Astrocytes contribute to remote memory formation by modulating hippocampal-cortical communication during learning. Nat. Neurosci. 2020, 23, 1229-1239. [CrossRef]

32. Windrem, M.S.; Osipovitch, M.; Liu, Z.; Bates, J.; Chandler-Militello, D.; Zou, L.; Munir, J.; Schanz, S.; McCoy, K.; Miller, R.H.; et al Human iPSC Glial Mouse Chimeras Reveal Glial Contributions to Schizophrenia. Cell Stem Cell 2017, 21, 195-208.e196. [CrossRef]

33. Marty, N.; Dallaporta, M.; Foretz, M.; Emery, M.; Tarussio, D.; Bady, I.; Binnert, C.; Beermann, F.; Thorens, B. Regulation of glucagon secretion by glucose transporter type 2 (glut2) and astrocyte-dependent glucose sensors. J. Clin. Investig. 2005, 115, 3545-3553. [CrossRef] [PubMed]

34. Argaw, A.T.; Asp, L.; Zhang, J.; Navrazhina, K.; Pham, T.; Mariani, J.N.; Mahase, S.; Dutta, D.J.; Seto, J.; Kramer, E.G.; et al. Astrocyte-derived VEGF-A drives blood-brain barrier disruption in CNS inflammatory disease. J. Clin. Investig. 2012, 122, 2454-2468. [CrossRef]

35. Michinaga, S.; Koyama, Y. Dual Roles of Astrocyte-Derived Factors in Regulation of Blood-Brain Barrier Function after Brain Damage. Int J. Mol. Sci. 2019, 20, 571. [CrossRef] [PubMed]

36. Luissint, A.C.; Artus, C.; Glacial, F.; Ganeshamoorthy, K.; Couraud, P.O. Tight junctions at the blood brain barrier: Physiological architecture and disease-associated dysregulation. Fluids Barriers CNS 2012, 9, 23. [CrossRef] [PubMed]

37. Mogi, M.; Horiuchi, M. Neurovascular coupling in cognitive impairment associated with diabetes mellitus. Circ. J. 2011, 75, 1042-1048. [CrossRef]

38. Taheri, S.; Gasparovic, C.; Huisa, B.N.; Adair, J.C.; Edmonds, E.; Prestopnik, J.; Grossetete, M.; Shah, N.J.; Wills, J.; Qualls, C.; et al. Blood-brain barrier permeability abnormalities in vascular cognitive impairment. Stroke 2011, 42, 2158-2163. [CrossRef]

39. Nation, D.A.; Sweeney, M.D.; Montagne, A.; Sagare, A.P.; D’Orazio, L.M.; Pachicano, M.; Sepehrband, F.; Nelson, A.R.; Buennagel, D.P.; Harrington, M.G.; et al. Blood-brain barrier breakdown is an early biomarker of human cognitive dysfunction. Nat. Med. 2019, 25, 270-276. [CrossRef]

40. Price, B.R.; Norris, C.M.; Sompol, P.; Wilcock, D.M. An emerging role of astrocytes in vascular contributions to cognitive impairment and dementia. J. Neurochem. 2018, 144, 644-650. [CrossRef]

41. Yang, S.; Gu, C.; Mandeville, E.T.; Dong, Y.; Esposito, E.; Zhang, Y.; Yang, G.; Shen, Y.; Fu, X.; Lo, E.H.; et al. Anesthesia and Surgery Impair Blood-Brain Barrier and Cognitive Function in Mice. Front. Immunol. 2017, 8, 902. [CrossRef]

42. Pan, Y.; Short, J.L.; Choy, K.H.; Zeng, A.X.; Marriott, P.J.; Owada, Y.; Scanlon, M.J.; Porter, C.J.; Nicolazzo, J.A. Fatty AcidBinding Protein 5 at the Blood-Brain Barrier Regulates Endogenous Brain Docosahexaenoic Acid Levels and Cognitive Function. J. Neurosci. 2016, 36, 11755-11767. [CrossRef]

43. Bauer, K.; Kornhuber, J. Blood-cerebrospinal fluid barrier in schizophrenic patients. Eur. Arch. Psychiatry Neurol. Sci. 1987, 236, 257-259. [CrossRef] [PubMed]

44. Kirch, D.G.; Kaufmann, C.A.; Papadopoulos, N.M.; Martin, B.; Weinberger, D.R. Abnormal cerebrospinal fluid protein indices in schizophrenia. Biol. Psychiatry 1985, 20, 1039-1046. [CrossRef]

45. Kirch, D.G.; Alexander, R.C.; Suddath, R.L.; Papadopoulos, N.M.; Kaufmann, C.A.; Daniel, D.G.; Wyatt, R.J. Blood-CSF barrier permeability and central nervous system immunoglobulin G in schizophrenia. J. Neural. Transm. Gen. Sect. 1992, 89, 219-232. [CrossRef]

46. Muller, N.; Ackenheil, M. Immunoglobulin and albumin content of cerebrospinal fluid in schizophrenic patients: Relationship to negative symptomatology. Schizophr. Res. 1995, 14, 223-228. [CrossRef]

47. Orlovska-Waast, S.; Kohler-Forsberg, O.; Brix, S.W.; Nordentoft, M.; Kondziella, D.; Krogh, J.; Benros, M.E. Cerebrospinal fluid markers of inflammation and infections in schizophrenia and affective disorders: A systematic review and meta-analysis. Mol. Psychiatry 2019, 24, 869-887. [CrossRef] [PubMed]

48. Meixensberger, S.; Bechter, K.; Dersch, R.; Feige, B.; Maier, S.; Schiele, M.A.; Runge, K.; Denzel, D.; Nickel, K.; Spieler, D.; et al. Sex difference in cerebrospinal fluid/blood albumin quotients in patients with schizophreniform and affective psychosis. Fluids Barriers CNS 2020, 17, 67. [CrossRef] [PubMed]

49. Lara, D.R.; Gama, C.S.; Belmonte-de-Abreu, P.; Portela, L.V.; Goncalves, C.A.; Fonseca, M.; Hauck, S.; Souza, D.O. Increased serum S100B protein in schizophrenia: A study in medication-free patients. J. Psychiatr. Res. 2001, 35, 11-14. [CrossRef]

50. Greene, C.; Kealy, J.; Humphries, M.M.; Gong, Y.; Hou, J.; Hudson, N.; Cassidy, L.M.; Martiniano, R.; Shashi, V.; Hooper, S.R.; et al. Dose-dependent expression of claudin-5 is a modifying factor in schizophrenia. Mol. Psychiatry 2018, 23, 2156-2166. [CrossRef]

51. Riedel, G.; Platt, B.; Micheau, J. Glutamate receptor function in learning and memory. Behav. Brain Res. 2003, 140, 1-47. [CrossRef]

52. Parsons, C.G.; Danysz, W.; Quack, G. Glutamate in CNS disorders as a target for drug development: An update. Drug News Perspect 1998, 11, 523-569. [CrossRef] [PubMed]

53. Mothet, J.P.; Parent, A.T.; Wolosker, H.; Brady, R.O., Jr.; Linden, D.J.; Ferris, C.D.; Rogawski, M.A.; Snyder, S.H. D-serine is an endogenous ligand for the glycine site of the N-methyl-D-aspartate receptor. Proc. Natl. Acad. Sci. USA 2000, 97, $4926-4931$. [CrossRef] [PubMed]

54. Bergeron, R.; Meyer, T.M.; Coyle, J.T.; Greene, R.W. Modulation of N-methyl-D-aspartate receptor function by glycine transport. Proc. Natl. Acad. Sci. USA 1998, 95, 15730-15734. [CrossRef]

55. Chen, L.; Muhlhauser, M.; Yang, C.R. Glycine tranporter-1 blockade potentiates NMDA-mediated responses in rat prefrontal cortical neurons in vitro and in vivo. J. Neurophysiol. 2003, 89, 691-703. [CrossRef] 
56. Borowsky, B.; Mezey, E.; Hoffman, B.J. Two glycine transporter variants with distinct localization in the CNS and peripheral tissues are encoded by a common gene. Neuron 1993, 10, 851-863. [CrossRef]

57. Papouin, T.; Dunphy, J.; Tolman, M.; Foley, J.C.; Haydon, P.G. Astrocytic control of synaptic function. Philos Trans. R Soc. Lond B Biol. Sci. 2017, 372. [CrossRef] [PubMed]

58. Martinez-Lozada, Z.; Ortega, A. Glutamatergic Transmission: A Matter of Three. Neural Plast. 2015, 2015, 787396. [CrossRef]

59. Xin, W.; Mironova, Y.A.; Shen, H.; Marino, R.A.M.; Waisman, A.; Lamers, W.H.; Bergles, D.E.; Bonci, A. Oligodendrocytes Support Neuronal Glutamatergic Transmission via Expression of Glutamine Synthetase. Cell Rep. 2019, 27, 2262-2271. [CrossRef]

60. Ehmsen, J.T.; Ma, T.M.; Sason, H.; Rosenberg, D.; Ogo, T.; Furuya, S.; Snyder, S.H.; Wolosker, H. D-serine in glia and neurons derives from 3-phosphoglycerate dehydrogenase. J. Neurosci. 2013, 33, 12464-12469. [CrossRef]

61. Yamasaki, M.; Yamada, K.; Furuya, S.; Mitoma, J.; Hirabayashi, Y.; Watanabe, M. 3-Phosphoglycerate dehydrogenase, a key enzyme for l-serine biosynthesis, is preferentially expressed in the radial glia/astrocyte lineage and olfactory ensheathing glia in the mouse brain. J. Neurosci. 2001, 21, 7691-7704. [CrossRef]

62. Neame, S.; Safory, H.; Radzishevsky, I.; Touitou, A.; Marchesani, F.; Marchetti, M.; Kellner, S.; Berlin, S.; Foltyn, V.N.; Engelender, S.; et al. The NMDA receptor activation by d-serine and glycine is controlled by an astrocytic Phgdh-dependent serine shuttle. Proc. Natl. Acad. Sci. USA 2019, 116, 20736-20742. [CrossRef] [PubMed]

63. Yang, J.H.; Wada, A.; Yoshida, K.; Miyoshi, Y.; Sayano, T.; Esaki, K.; Kinoshita, M.O.; Tomonaga, S.; Azuma, N.; Watanabe, M.; et al. Brain-specific Phgdh deletion reveals a pivotal role for L-serine biosynthesis in controlling the level of D-serine, an N-methyl-Daspartate receptor co-agonist, in adult brain. J. Biol Chem. 2010, 285, 41380-41390. [CrossRef] [PubMed]

64. Eulenburg, V.; Armsen, W.; Betz, H.; Gomeza, J. Glycine transporters: Essential regulators of neurotransmission. Trends Biochem. Sci. 2005, 30, 325-333. [CrossRef]

65. Ciruela, F.; Casadó, V.; Rodrigues, R.J.; Luján, R.; Burgueño, J.; Canals, M.; Borycz, J.; Rebola, N.; Goldberg, S.R.; Mallol, J.; et al. Presynaptic control of striatal glutamatergic neurotransmission by adenosine A1-A2A receptor heteromers. J. Neurosci. 2006, 26, 2080-2087. [CrossRef] [PubMed]

66. Matos, M.; Shen, H.Y.; Augusto, E.; Wang, Y.; Wei, C.J.; Wang, Y.T.; Agostinho, P.; Boison, D.; Cunha, R.A.; Chen, J.F. Deletion of adenosine A2A receptors from astrocytes disrupts glutamate homeostasis leading to psychomotor and cognitive impairment: Relevance to schizophrenia. Biol. Psychiatry 2015, 78, 763-774. [CrossRef] [PubMed]

67. Ballesteros-Yáñez, I.; Castillo, C.A.; Merighi, S.; Gessi, S. The role of adenosine receptors in psychostimulant addiction. Front. Pharmacol. 2018, 8, 985. [CrossRef] [PubMed]

68. Halberstadt, A.L. The phencyclidine-glutamate model of schizophrenia. Clin. Neuropharmacol. 1995, 18, 237-249. [CrossRef] [PubMed]

69. Krystal, J.H.; Karper, L.P.; Seibyl, J.P.; Freeman, G.K.; Delaney, R.; Bremner, J.D.; Heninger, G.R.; Bowers, M.B., Jr.; Charney, D.S. Subanesthetic effects of the noncompetitive NMDA antagonist, ketamine, in humans. Psychotomimetic, perceptual, cognitive, and neuroendocrine responses. Arch. Gen. Psychiatry 1994, 51, 199-214. [CrossRef]

70. Cull-Candy, S.; Brickley, S.; Farrant, M. NMDA receptor subunits: Diversity, development and disease. Curr. Opin. Neurobiol. 2001, 11, 327-335. [CrossRef]

71. Bickel, S.; Javitt, D.C. Neurophysiological and neurochemical animal models of schizophrenia: Focus on glutamate. Behav. Brain Res. 2009, 204, 352-362. [CrossRef] [PubMed]

72. Katsel, P.; Byne, W.; Roussos, P.; Tan, W.; Siever, L.; Haroutunian, V. Astrocyte and glutamate markers in the superficial, deep, and white matter layers of the anterior cingulate gyrus in schizophrenia. Neuropsychopharmacology 2011, 36, 1171-1177. [CrossRef]

73. Steffek, A.E.; McCullumsmith, R.E.; Haroutunian, V.; Meador-Woodruff, J.H. Cortical expression of glial fibrillary acidic protein and glutamine synthetase is decreased in schizophrenia. Schizophr. Res. 2008, 103, 71-82. [CrossRef] [PubMed]

74. McCullumsmith, R.E.; O’Donovan, S.M.; Drummond, J.B.; Benesh, F.S.; Simmons, M.; Roberts, R.; Lauriat, T.; Haroutunian, V.; Meador-Woodruff, J.H. Cell-specific abnormalities of glutamate transporters in schizophrenia: Sick astrocytes and compensating relay neurons? Mol. Psychiatry 2016, 21, 823-830. [CrossRef] [PubMed]

75. Arguello, P.A.; Gogos, J.A. Modeling madness in mice: One piece at a time. Neuron 2006, 52, 179-196. [CrossRef]

76. Powell, C.M.; Miyakawa, T. Schizophrenia-relevant behavioral testing in rodent models: A uniquely human disorder? Biol. Psychiatry 2006, 59, 1198-1207. [CrossRef] [PubMed]

77. Kellendonk, C.; Simpson, E.H.; Kandel, E.R. Modeling cognitive endophenotypes of schizophrenia in mice. Trends Neurosci. 2009, 32, 347-358. [CrossRef]

78. Nestler, E.J.; Hyman, S.E. Animal models of neuropsychiatric disorders. Nat. Neurosci. 2010, 13, 1161-1169. [CrossRef] [PubMed]

79. Waddington, J.L.; Corvin, A.P.; Donohoe, G.; O'Tuathaigh, C.M.; Mitchell, K.J.; Gill, M. Functional genomics and schizophrenia: Endophenotypes and mutant models. Psychiatr. Clin. North. Am. 2007, 30, 365-399. [CrossRef]

80. Xia, M.; Abazyan, S.; Jouroukhin, Y.; Pletnikov, M. Behavioral sequelae of astrocyte dysfunction: Focus on animal models of schizophrenia. Schizophr. Res. 2016, 176, 72-82. [CrossRef] [PubMed]

81. Schousboe, A.; Scafidi, S.; Bak, L.K.; Waagepetersen, H.S.; McKenna, M.C. Glutamate metabolism in the brain focusing on astrocytes. Adv. Neurobiol. 2014, 11, 13-30. [CrossRef]

82. Burbaeva, G.; Boksha, I.S.; Turishcheva, M.S.; Vorobyeva, E.A.; Savushkina, O.K.; Tereshkina, E.B. Glutamine synthetase and glutamate dehydrogenase in the prefrontal cortex of patients with schizophrenia. Prog. Neuropsychopharmacol. Biol. Psychiatry 2003, 27, 675-680. [CrossRef] 
83. Matute, C.; Melone, M.; Vallejo-Illarramendi, A.; Conti, F. Increased expression of the astrocytic glutamate transporter GLT-1 in the prefrontal cortex of schizophrenics. Glia 2005, 49, 451-455. [CrossRef] [PubMed]

84. O'Donovan, S.M.; Sullivan, C.R.; McCullumsmith, R.E. The role of glutamate transporters in the pathophysiology of neuropsychiatric disorders. NPJ Schizophr. 2017, 3, 32. [CrossRef] [PubMed]

85. Bellesi, M.; Melone, M.; Gubbini, A.; Battistacci, S.; Conti, F. GLT-1 upregulation impairs prepulse inhibition of the startle reflex in adult rats. Glia 2009, 57, 703-713. [CrossRef] [PubMed]

86. Matos-Ocasio, F.; Hernandez-Lopez, A.; Thompson, K.J. Ceftriaxone, a GLT-1 transporter activator, disrupts hippocampal learning in rats. Pharmacol. Biochem. Behav. 2014, 122, 118-121. [CrossRef]

87. Son, H.; Kim, S.; Jung, D.H.; Baek, J.H.; Lee, D.H.; Roh, G.S.; Kang, S.S.; Cho, G.J.; Choi, W.S.; Lee, D.K.; et al. Insufficient glutamine synthetase activity during synaptogenesis causes spatial memory impairment in adult mice. Sci. Rep. 2019, 9, 252. [CrossRef]

88. Hou, X.; Li, Y.; Huang, Y.; Zhao, H.; Gui, L. Adenosine receptor A1-A2a heteromers regulate EAAT2 expression and glutamate uptake via YY1-induced repression of PPARgamma transcription. PPAR Res. 2020, 2020, 2410264. [CrossRef]

89. Balu, D.T.; Coyle, J.T. The NMDA receptor 'glycine modulatory site' in schizophrenia: D-serine, glycine, and beyond. Curr. Opin. Pharmacol. 2015, 20, 109-115. [CrossRef] [PubMed]

90. Harvey, R.J.; Yee, B.K. Glycine transporters as novel therapeutic targets in schizophrenia, alcohol dependence and pain. Nat. Rev. Drug Discov. 2013, 12, 866-885. [CrossRef]

91. Marques, B.L.; Oliveira-Lima, O.C.; Carvalho, G.A.; de Almeida Chiarelli, R.; Ribeiro, R.I.; Parreira, R.C.; da Madeira Freitas, E.M.; Resende, R.R.; Klempin, F.; Ulrich, H.; et al. Neurobiology of glycine transporters: From molecules to behavior. Neurosci. Biobehav. Rev. 2020, 118, 97-110. [CrossRef]

92. Mihali, A.; Subramani, S.; Kaunitz, G.; Rayport, S.; Gaisler-Salomon, I. Modeling resilience to schizophrenia in genetically modified mice: A novel approach to drug discovery. Expert Rev. Neurother. 2012, 12, 785-799. [CrossRef] [PubMed]

93. Mohler, H.; Boison, D.; Singer, P.; Feldon, J.; Pauly-Evers, M.; Yee, B.K. Glycine transporter 1 as a potential therapeutic target for schizophrenia-related symptoms: Evidence from genetically modified mouse models and pharmacological inhibition. Biochem. Pharmacol. 2011, 81, 1065-1077. [CrossRef] [PubMed]

94. Tsai, G.; Ralph-Williams, R.J.; Martina, M.; Bergeron, R.; Berger-Sweeney, J.; Dunham, K.S.; Jiang, Z.; Caine, S.B.; Coyle, J.T. Gene knockout of glycine transporter 1: Characterization of the behavioral phenotype. Proc. Natl. Acad. Sci. USA 2004, 101, 8485-8490. [CrossRef]

95. Murtas, G.; Marcone, G.L.; Sacchi, S.; Pollegioni, L. L-serine synthesis via the phosphorylated pathway in humans. Cell Mol. Life Sci. 2020, 77, 5131-5148. [CrossRef]

96. Wolosker, H.; Blackshaw, S.; Snyder, S.H. Serine racemase: A glial enzyme synthesizing D-serine to regulate glutamate-N-methylD-aspartate neurotransmission. Proc. Natl. Acad. Sci. USA 1999, 96, 13409-13414. [CrossRef] [PubMed]

97. Park, H.K.; Shishido, Y.; Ichise-Shishido, S.; Kawazoe, T.; Ono, K.; Iwana, S.; Tomita, Y.; Yorita, K.; Sakai, T.; Fukui, K. Potential role for astroglial D-amino acid oxidase in extracellular D-serine metabolism and cytotoxicity. J. Biochem. 2006, 139, 295-304. [CrossRef] [PubMed]

98. Furuya, S.; Yoshida, K.; Kawakami, Y.; Yang, J.H.; Sayano, T.; Azuma, N.; Tanaka, H.; Kuhara, S.; Hirabayashi, Y. Inactivation of the 3-phosphoglycerate dehydrogenase gene in mice: Changes in gene expression and associated regulatory networks resulting from serine deficiency. Funct. Integr. Genom. 2008, 8, 235-249. [CrossRef]

99. Le Douce, J.; Maugard, M.; Veran, J.; Matos, M.; Jego, P.; Vigneron, P.A.; Faivre, E.; Toussay, X.; Vandenberghe, M.; Balbastre, Y.; et al. Impairment of Glycolysis-Derived l-Serine Production in Astrocytes Contributes to Cognitive Deficits in Alzheimer's Disease. Cell Metab. 2020, 31, 503-517.e508. [CrossRef]

100. Balu, D.T.; Takagi, S.; Puhl, M.D.; Benneyworth, M.A.; Coyle, J.T. D-serine and serine racemase are localized to neurons in the adult mouse and human forebrain. Cell Mol. Neurobiol. 2014, 34, 419-435. [CrossRef] [PubMed]

101. Benneyworth, M.A.; Li, Y.; Basu, A.C.; Bolshakov, V.Y.; Coyle, J.T. Cell selective conditional null mutations of serine racemase demonstrate a predominate localization in cortical glutamatergic neurons. Cell Mol. Neurobiol. 2012, 32, 613-624. [CrossRef]

102. Verrall, L.; Burnet, P.W.; Betts, J.F.; Harrison, P.J. The neurobiology of D-amino acid oxidase and its involvement in schizophrenia. Mol. Psychiatry 2010, 15, 122-137. [CrossRef]

103. Schell, M.J.; Molliver, M.E.; Snyder, S.H. D-serine, an endogenous synaptic modulator: Localization to astrocytes and glutamatestimulated release. Proc. Natl. Acad. Sci. USA 1995, 92, 3948-3952. [CrossRef]

104. Balu, D.T.; Li, Y.; Puhl, M.D.; Benneyworth, M.A.; Basu, A.C.; Takagi, S.; Bolshakov, V.Y.; Coyle, J.T. Multiple risk pathways for schizophrenia converge in serine racemase knockout mice, a mouse model of NMDA receptor hypofunction. Proc. Natl. Acad. Sci. USA 2013, 110, E2400-E2409. [CrossRef]

105. Basu, A.C.; Tsai, G.E.; Ma, C.L.; Ehmsen, J.T.; Mustafa, A.K.; Han, L.; Jiang, Z.I.; Benneyworth, M.A.; Froimowitz, M.P.; Lange, N.; et al. Targeted disruption of serine racemase affects glutamatergic neurotransmission and behavior. Mol. Psychiatry 2009, 14, 719-727. [CrossRef] [PubMed]

106. DeVito, L.M.; Balu, D.T.; Kanter, B.R.; Lykken, C.; Basu, A.C.; Coyle, J.T.; Eichenbaum, H. Serine racemase deletion disrupts memory for order and alters cortical dendritic morphology. Genes Brain Behav. 2011, 10, 210-222. [CrossRef] [PubMed]

107. Matveeva, T.M.; Pisansky, M.T.; Young, A.; Miller, R.F.; Gewirtz, J.C. Sociality deficits in serine racemase knockout mice. Brain Behav. 2019, 9, e01383. [CrossRef] [PubMed] 
108. Pei, J.C.; Hung, W.L.; Lin, B.X.; Shih, M.H.; Lu, L.Y.; Luo, D.Z.; Tai, H.C.; Studer, V.; Min, M.Y.; Lai, W.S. Therapeutic potential and underlying mechanism of sarcosine (N-methylglycine) in N-methyl-D-aspartate (NMDA) receptor hypofunction models of schizophrenia. J. Psychopharmacol. 2019, 33, 1288-1302. [CrossRef] [PubMed]

109. Labrie, V.; Wong, A.H.; Roder, J.C. Contributions of the D-serine pathway to schizophrenia. Neuropharmacology 2012, 62, 1484-1503. [CrossRef] [PubMed]

110. Sacchi, S.; Bernasconi, M.; Martineau, M.; Mothet, J.P.; Ruzzene, M.; Pilone, M.S.; Pollegioni, L.; Molla, G. pLG72 modulates intracellular D-serine levels through its interaction with D-amino acid oxidase: Effect on schizophrenia susceptibility. J. Biol. Chem. 2008, 283, 22244-22256. [CrossRef]

111. Hambsch, B.; Keyworth, H.; Lind, J.; Otte, D.M.; Racz, I.; Kitchen, I.; Bailey, A.; Zimmer, A. Chronic nicotine improves short-term memory selectively in a G72 mouse model of schizophrenia. Br. J. Pharmacol. 2014, 171, 1758-1771. [CrossRef]

112. Otte, D.M.; Bilkei-Gorzo, A.; Filiou, M.D.; Turck, C.W.; Yilmaz, O.; Holst, M.I.; Schilling, K.; Abou-Jamra, R.; Schumacher, J.; Benzel, I.; et al. Behavioral changes in G72/G30 transgenic mice. Eur Neuropsychopharmacol. 2009, 19, 339-348. [CrossRef]

113. Otte, D.M.; Sommersberg, B.; Kudin, A.; Guerrero, C.; Albayram, O.; Filiou, M.D.; Frisch, P.; Yilmaz, O.; Drews, E.; Turck, C.W.; et al. N-acetyl cysteine treatment rescues cognitive deficits induced by mitochondrial dysfunction in G72/G30 transgenic mice. Neuropsychopharmacology 2011, 36, 2233-2243. [CrossRef]

114. Quintana, A.; Erta, M.; Ferrer, B.; Comes, G.; Giralt, M.; Hidalgo, J. Astrocyte-specific deficiency of interleukin-6 and its receptor reveal specific roles in survival, body weight and behavior. Brain Behav. Immun. 2013, 27, 162-173. [CrossRef] [PubMed]

115. Lai, W.S.; Chang, C.Y.; Wong, W.R.; Pei, J.C.; Chen, Y.S.; Hong, W.L. Assessing schizophrenia-relevant cognitive and social deficits in mice: A selection of mouse behavioral tasks and potential therapeutic compounds. Curr. Pharm. Des. 2014, 20, 5139-5150. [CrossRef] [PubMed]

116. Young, J.W.; Powell, S.B.; Risbrough, V.; Marston, H.M.; Geyer, M.A. Using the MATRICS to guide development of a preclinical cognitive test battery for research in schizophrenia. Pharmacol. Ther. 2009, 122, 150-202. [CrossRef] [PubMed]

117. Barch, D.M.; Carter, C.S.; Arnsten, A.; Buchanan, R.W.; Cohen, J.D.; Geyer, M.; Green, M.F.; Krystal, J.H.; Nuechterlein, K.; Robbins, T.; et al. Selecting paradigms from cognitive neuroscience for translation into use in clinical trials: Proceedings of the third CNTRICS meeting. Schizophr. Bull. 2009, 35, 109-114. [CrossRef]

118. Velligan, D.I.; Kern, R.S.; Gold, J.M. Cognitive rehabilitation for schizophrenia and the putative role of motivation and expectancies. Schizophr. Bull. 2006, 32, 474-485. [CrossRef] [PubMed]

119. Vita, A.; Barlati, S.; Ceraso, A.; Nibbio, G.; Ariu, C.; Deste, G.; Wykes, T. Effectiveness, Core Elements, and Moderators of Response of Cognitive Remediation for Schizophrenia: A Systematic Review and Meta-analysis of Randomized Clinical Trials. JAMA Psychiatry 2021. [CrossRef] [PubMed]

120. Elvevåg, B.; Goldberg, T.E. Cognitive impairment in schizophrenia is the core of the disorder. Crit. Rev. Neurobiol. 2000, 14, 1-21. [CrossRef]

121. Crinella, F.M.; Yu, J. Brain mechanisms in problem solving and intelligence: A replication and extension. Intelligence 1995, 21, 225-246. [CrossRef]

122. Galsworthy, M.J.; Paya-Cano, J.L.; Liu, L.; Monleon, S.; Gregoryan, G.; Fernandes, C.; Schalkwyk, L.C.; Plomin, R. Assessing reliability, heritability and general cognitive ability in a battery of cognitive tasks for laboratory mice. Behav. Genet. 2005, 35, 675-692. [CrossRef] [PubMed]

123. Galsworthy, M.J.; Paya-Cano, J.L.; Monleón, S.; Plomin, R. Evidence for general cognitive ability (g) in heterogeneous stock mice and an analysis of potential confounds. Genes Brain Behav. 2002, 1, 88-95. [CrossRef] [PubMed]

124. Ben Abdallah, N.M.; Fuss, J.; Trusel, M.; Galsworthy, M.J.; Bobsin, K.; Colacicco, G.; Deacon, R.M.; Riva, M.A.; Kellendonk, C.; Sprengel, R.; et al. The puzzle box as a simple and efficient behavioral test for exploring impairments of general cognition and executive functions in mouse models of schizophrenia. Exp. Neurol. 2011, 227, 42-52. [CrossRef] [PubMed]

125. Milenkovic, M.; Mielnik, C.A.; Ramsey, A.J. NMDA receptor-deficient mice display sexual dimorphism in the onset and severity of behavioural abnormalities. Genes Brain. Behav. 2014, 13, 850-862. [CrossRef]

126. Cornblatt, B.A.; Keilp, J.G. Impaired attention, genetics, and the pathophysiology of schizophrenia. Schizophr. Bull. 1994, 20, 31-46. [CrossRef] [PubMed]

127. Chudasama, Y.; Robbins, T.W. Psychopharmacological approaches to modulating attention in the five-choice serial reaction time task: Implications for schizophrenia. Psychopharmacology 2004, 174, 86-98. [CrossRef] [PubMed]

128. Tucci, V.; Hardy, A.; Nolan, P.M. A comparison of physiological and behavioural parameters in C57BL/6J mice undergoing food or water restriction regimes. Behav. Brain Res. 2006, 173, 22-29. [CrossRef]

129. Alkam, T.; Hiramatsu, M.; Mamiya, T.; Aoyama, Y.; Nitta, A.; Yamada, K.; Kim, H.C.; Nabeshima, T. Evaluation of object-based attention in mice. Behav. Brain Res. 2011, 220, 185-193. [CrossRef]

130. Wulaer, B.; Kunisawa, K.; Kubota, H.; Suento, W.J.; Saito, K.; Mouri, A.; Nabeshima, T. Prefrontal cortex, dorsomedial striatum, and dentate gyrus are necessary in the object-based attention test in mice. Mol. Brain 2020, 13, 171. [CrossRef] [PubMed]

131. Salamone, J.D.; Correa, M.; Ferrigno, S.; Yang, J.H.; Rotolo, R.A.; Presby, R.E. The Psychopharmacology of Effort-Related Decision Making: Dopamine, Adenosine, and Insights into the Neurochemistry of Motivation. Pharmacol. Rev. 2018, 70, 747-762. [CrossRef]

132. Lewis, D.A.; Sweet, R.A. Schizophrenia from a neural circuitry perspective: Advancing toward rational pharmacological therapies. J. Clin. Investig. 2009, 119, 706-716. [CrossRef] 
133. Salamone, J.D.; Steinpreis, R.E.; McCullough, L.D.; Smith, P.; Grebel, D.; Mahan, K. Haloperidol and nucleus accumbens dopamine depletion suppress lever pressing for food but increase free food consumption in a novel food choice procedure. Psychopharmacology 1991, 104, 515-521. [CrossRef]

134. Sommer, S.; Danysz, W.; Russ, H.; Valastro, B.; Flik, G.; Hauber, W. The dopamine reuptake inhibitor MRZ-9547 increases progressive ratio responding in rats. Int J. Neuropsychopharmacol. 2014, 17, 2045-2056. [CrossRef]

135. Salamone, J.D.; Cousins, M.S.; Bucher, S. Anhedonia or anergia? Effects of haloperidol and nucleus accumbens dopamine depletion on instrumental response selection in a T-maze cost/benefit procedure. Behav Brain Res. 1994, 65, 221-229. [CrossRef]

136. Yohn, S.E.; Thompson, C.; Randall, P.A.; Lee, C.A.; Muller, C.E.; Baqi, Y.; Correa, M.; Salamone, J.D. The VMAT-2 inhibitor tetrabenazine alters effort-related decision making as measured by the T-maze barrier choice task: Reversal with the adenosine A2A antagonist MSX-3 and the catecholamine uptake blocker bupropion. Psychopharmacology 2015, 232, 1313-1323. [CrossRef]

137. Farrar, A.M.; Font, L.; Pereira, M.; Mingote, S.; Bunce, J.G.; Chrobak, J.J.; Salamone, J.D. Forebrain circuitry involved in effortrelated choice: Injections of the GABAA agonist muscimol into ventral pallidum alter response allocation in food-seeking behavior. Neuroscience 2008, 152, 321-330. [CrossRef]

138. Floresco, S.B.; Tse, M.T.; Ghods-Sharifi, S. Dopaminergic and glutamatergic regulation of effort- and delay-based decision making. Neuropsychopharmacology 2008, 33, 1966-1979. [CrossRef] [PubMed]

139. Dallerac, G.; Chever, O.; Rouach, N. How do astrocytes shape synaptic transmission? Insights from electrophysiology. Front. Cell Neurosci. 2013, 7, 159. [CrossRef] [PubMed]

140. Rosen, A.M.; Spellman, T.; Gordon, J.A. Electrophysiological endophenotypes in rodent models of schizophrenia and psychosis. Biol. Psychiatry 2015, 77, 1041-1049. [CrossRef]

141. Pirttimaki, T.M.; Sims, R.E.; Saunders, G.; Antonio, S.A.; Codadu, N.K.; Parri, H.R. Astrocyte-Mediated Neuronal Synchronization Properties Revealed by False Gliotransmitter Release. J. Neurosci. 2017, 37, 9859-9870. [CrossRef] [PubMed]

142. Srivastava, I.; Vazquez-Juarez, E.; Lindskog, M. Reducing Glutamate Uptake in Rat Hippocampal Slices Enhances Astrocytic Membrane Depolarization While Down-Regulating CA3-CA1 Synaptic Response. Front. Synaptic Neurosci. 2020, 12, 37. [CrossRef]

143. Mishima, T.; Sakatani, S.; Hirase, H. Intracellular labeling of single cortical astrocytes in vivo. J. Neurosci. Methods 2007, 166, 32-40. [CrossRef] [PubMed]

144. Poskanzer, K.E.; Yuste, R. Astrocytes regulate cortical state switching in vivo. Proc. Natl. Acad. Sc.i USA 2016, 113, E2675-E2684. [CrossRef] [PubMed]

145. Chen, Y.W.; Kao, H.Y.; Min, M.Y.; Lai, W.S. A sex- and region-specific role of akt1 in the modulation of methamphetamineinduced hyperlocomotion and striatal neuronal activity: Implications in schizophrenia and methamphetamine-induced psychosis. Schizophr. Bull. 2014, 40, 388-398. [CrossRef] [PubMed]

146. Huang, C.H.; Pei, J.C.; Luo, D.Z.; Chen, C.; Chen, Y.W.; Lai, W.S. Investigation of gene effects and epistatic interactions between Akt1 and neuregulin 1 in the regulation of behavioral phenotypes and social functions in genetic mouse models of schizophrenia. Front. Behav. Neurosci. 2014, 8, 455. [CrossRef] [PubMed]

147. Patel, N.H.; Vyas, N.S.; Puri, B.K.; Nijran, K.S.; Al-Nahhas, A. Positron emission tomography in schizophrenia: A new perspective. J. Nucl. Med. 2010, 51, 511-520. [CrossRef]

148. Virdee, K.; Cumming, P.; Caprioli, D.; Jupp, B.; Rominger, A.; Aigbirhio, F.I.; Fryer, T.D.; Riss, P.J.; Dalley, J.W. Applications of positron emission tomography in animal models of neurological and neuropsychiatric disorders. Neurosci. Biobehav. Rev. 2012, 36, 1188-1216. [CrossRef]

149. Zimmer, E.R.; Parent, M.J.; Souza, D.G.; Leuzy, A.; Lecrux, C.; Kim, H.I.; Gauthier, S.; Pellerin, L.; Hamel, E.; Rosa-Neto, P. [(18)F]FDG PET signal is driven by astroglial glutamate transport. Nat. Neurosci. 2017, 20, 393-395. [CrossRef] [PubMed]

150. Carter, S.F.; Scholl, M.; Almkvist, O.; Wall, A.; Engler, H.; Langstrom, B.; Nordberg, A. Evidence for astrocytosis in prodromal Alzheimer disease provided by 11C-deuterium-L-deprenyl: A multitracer PET paradigm combining 11C-Pittsburgh compound B and 18F-FDG. J. Nucl. Med. 2012, 53, 37-46. [CrossRef]

151. Rodriguez-Vieitez, E.; Ni, R.; Gulyas, B.; Toth, M.; Haggkvist, J.; Halldin, C.; Voytenko, L.; Marutle, A.; Nordberg, A. Astrocytosis precedes amyloid plaque deposition in Alzheimer APPswe transgenic mouse brain: A correlative positron emission tomography and in vitro imaging study. Eur. J. Nucl. Med. Mol. Imaging 2015, 42, 1119-1132. [CrossRef]

152. Owen, F.; Crow, T.J.; Frith, C.D.; Johnson, J.A.; Johnstone, E.C.; Lofthouse, R.; Owens, D.G.; Poulter, M. Selective decreases in MAO-B activity in post-mortem brains from schizophrenic patients with type II syndrome. Br. J. Psychiatry J. Ment. Sci. 1987, 151, 514-519. [CrossRef] [PubMed]

153. Wei, Y.L.; Li, C.X.; Li, S.B.; Liu, Y.; Hu, L. Association study of monoamine oxidase A/B genes and schizophrenia in Han Chinese. Behav. Brain Funct. 2011, 7, 42. [CrossRef] [PubMed]

154. Merali, Z.; Wong, T.; Leung, J.; Gao, M.M.; Mikulis, D.; Kassner, A. Dynamic contrast-enhanced MRI and CT provide comparable measurement of blood-brain barrier permeability in a rodent stroke model. Magn. Reson. Imaging 2015, 33, 1007-1012. [CrossRef]

155. Yu, M.; Yang, D.; Wang, M.; Wei, X.; Li, W. Early stage of diffusional kurtosis imaging and dynamic contrast-enhanced magnetic resonance imaging correlated with long-term neurocognitive function after experimental traumatic brain injury. Neurosci. Lett. 2019, 705, 206-211. [CrossRef] [PubMed]

156. Dickie, B.R.; Vandesquille, M.; Ulloa, J.; Boutin, H.; Parkes, L.M.; Parker, G.J.M. Water-exchange MRI detects subtle blood-brain barrier breakdown in Alzheimer's disease rats. Neuroimage 2019, 184, 349-358. [CrossRef] [PubMed] 
157. Benveniste, H.; Lee, H.; Ozturk, B.; Chen, X.; Koundal, S.; Vaska, P.; Tannenbaum, A.; Volkow, N.D. Glymphatic Cerebrospinal Fluid and Solute Transport Quantified by MRI and PET Imaging. Neuroscience 2020. [CrossRef] [PubMed]

158. Saxton, M.J. Single-particle tracking: Connecting the dots. Nat. Methods 2008, 5, 671-672. [CrossRef]

159. Shen, H.; Tauzin, L.J.; Baiyasi, R.; Wang, W.; Moringo, N.; Shuang, B.; Landes, C.F. Single Particle Tracking: From Theory to Biophysical Applications. Chem. Rev. 2017, 117, 7331-7376. [CrossRef]

160. Al Awabdh, S.; Gupta-Agarwal, S.; Sheehan, D.F.; Muir, J.; Norkett, R.; Twelvetrees, A.E.; Griffin, L.D.; Kittler, J.T. Neuronal activity mediated regulation of glutamate transporter GLT-1 surface diffusion in rat astrocytes in dissociated and slice cultures. Glia 2016, 64, 1252-1264. [CrossRef]

161. Arizono, M.; Bannai, H.; Nakamura, K.; Niwa, F.; Enomoto, M.; Matsu-Ura, T.; Miyamoto, A.; Sherwood, M.W.; Nakamura, T.; Mikoshiba, K. Receptor-selective diffusion barrier enhances sensitivity of astrocytic processes to metabotropic glutamate receptor stimulation. Sci. Signal. 2012, 5, ra27. [CrossRef]

162. Crane, J.M.; Van Hoek, A.N.; Skach, W.R.; Verkman, A.S. Aquaporin-4 dynamics in orthogonal arrays in live cells visualized by quantum dot single particle tracking. Mol. Biol. Cell 2008, 19, 3369-3378. [CrossRef] [PubMed]

163. Bannai, H. Molecular membrane dynamics: Insights into synaptic function and neuropathological disease. Neurosci. Res. 2018, 129, 47-56. [CrossRef] [PubMed]

164. Ballas, N.; Lioy, D.T.; Grunseich, C.; Mandel, G. Non-cell autonomous influence of MeCP2-deficient glia on neuronal dendritic morphology. Nat. Neurosci. 2009, 12, 311-317. [CrossRef] [PubMed]

165. Jacobs, S.; Doering, L.C. Astrocytes prevent abnormal neuronal development in the fragile x mouse. J. Neurosci. 2010, 30, 4508-4514. [CrossRef] [PubMed]

166. Rajkowska, G.; Stockmeier, C.A. Astrocyte pathology in major depressive disorder: Insights from human postmortem brain tissue. Curr. Drug Targets 2013, 14, 1225-1236. [CrossRef] [PubMed]

167. Peng, L.; Li, B.; Verkhratsky, A. Targeting astrocytes in bipolar disorder. Expert Rev. Neurother. 2016, 16, 649-657. [CrossRef]

168. Acosta, C.; Anderson, H.D.; Anderson, C.M. Astrocyte dysfunction in Alzheimer disease. J. Neurosci. Res. 2017, 95, 2430-2447. [CrossRef]

169. Bochukova, E.G.; Lawler, K.; Croizier, S.; Keogh, J.M.; Patel, N.; Strohbehn, G.; Lo, K.K.; Humphrey, J.; Hokken-Koelega, A.; Damen, L.; et al. A Transcriptomic Signature of the Hypothalamic Response to Fasting and BDNF Deficiency in Prader-Willi Syndrome. Cell Rep. 2018, 22, 3401-3408. [CrossRef]

170. Booth, H.D.E.; Hirst, W.D.; Wade-Martins, R. The Role of Astrocyte Dysfunction in Parkinson's Disease Pathogenesis. Trends Neurosci. 2017, 40, 358-370. [CrossRef] 